\title{
أهلية المتأخرين في الحكم على الحديث بين النظرية والتطبيق
}

Kabul Tarihi: 13.10.2015

Gönderim Tarihi: 06.01.2016

Makale Türü: Araştırma Makalesi

ORCID ID: http://orcid.org/0000-0003-2097-9343

\begin{abstract}
Abdel Gani ADA*
ملخص المقالة

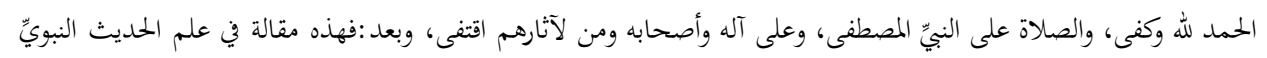

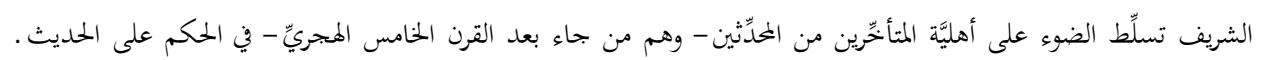

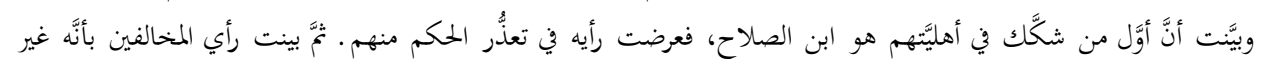

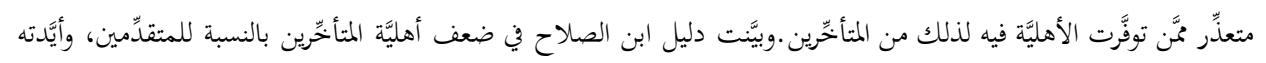

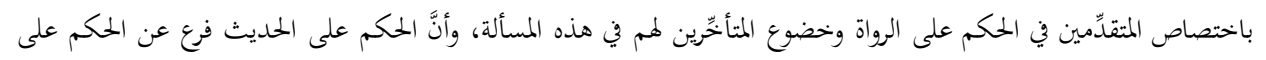

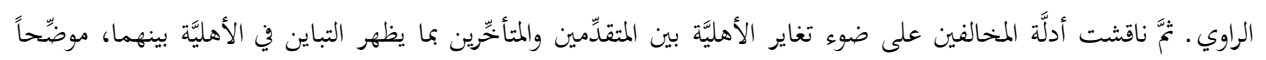

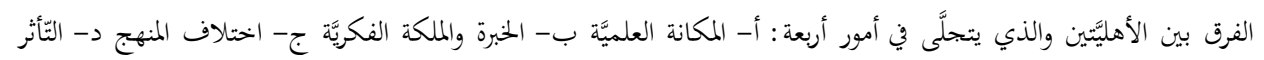

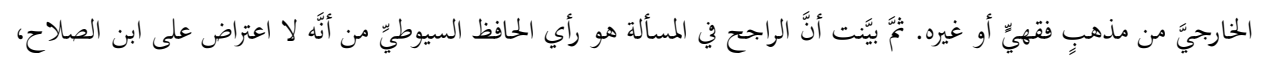

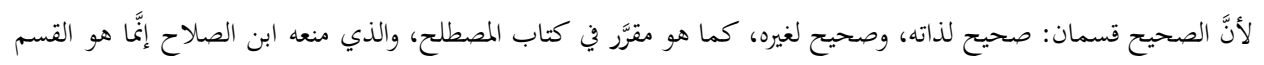

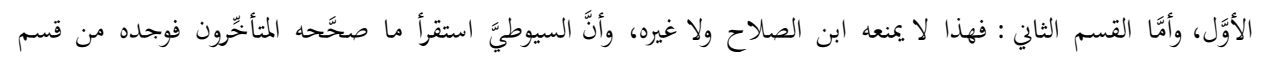
الصحيح لغيره لا لذاته. وفي الخاتمة سجلت أهمَّ النتائج والتوصيات التي رأيتها نافعةً في بحال النقد الحديثيّ. الكلمات المفتاح: الحديث، الحكم، المتأخرين، الأهلية، المتقدمين.
\end{abstract}

\section{Müteahhirîn Âlimlerinin Hadis Hakkında Hüküm Verme Konusundaki Ehliyeti -Teorik ve Pratik Açıdan Bir İnceleme-} Öz

Bu makale, Hadis ilmine dair olup, hadisle ilgili hüküm verme konusunda H. 5 . asır sonrası gelen müteahhir muhaddislerin ehliyetini açıklamaktadır. Makalede onların ehliyetine dair ilk defa şüphe uyandıranın İbnü's-Salâh olduğu beyan edilmiştir. Bu bağlamda onların hadisle ilgili hüküm veremeyeceği şeklindeki görüşü takdim edilmiştir. Sonra muhaliflerin, müteahhirîn âlimler arasında

Yrd. Doç. Dr., Amasya Üniversitesi, İlahiyat Fakültesi, Temel İslam Bilimleri Bölümü. Assistant Professor, Amasya University, Faculty of Theology, Department of Basic Islamic Sciences. Amasya/Turkey (ada-abed@ hotmail.com). 


\section{0 | Abdel Gani ADA}

ehliyeti haiz kimseler için bunun mümkün olamayacağı şeklindeki kanaatleri belirtilmiştir. Akabinde İbnü's-Salah'ın, müeahhirinin mütekaddimine göre ehliyet bakımından zayıf olduğuna dair delili ortaya koyulmuştur. İbnü'sSalâh'ın görüşüne, mütekaddimînin raviler üzerine hüküm verme konusunda otorite olması, müteahhirînin ise onlara tabiiyyeti ve hadis hakkında hüküm vermeninin râvî hakkında hüküm vermenin bir cüz'ü oluşu ile destek verilmiştir. Sonra ehliyet hususunda aralarında farklılıklar görülmesine binaen, mütekaddimîn ile müteahhirîn arasında ehliyet farklılaşmalarının ışı̆̆ında muhaliflerin delilleri tartışılmıştır. Bu farklılıkların ilmi seviye, tecrübe ve fikri yetkinlik, yöntem farklılığı ve fikhi ya da başka bir mezhebten harici etkilenme olmak üzere dört konuda ortaya çıktığı açıklanmıştır. Sonra meselede tercihe şayan olan Süyûtî'nin görüşü beyan edilmiştir. Buna göre Süyûtî'nin İbnü'sSalâh'a itirazı söz konusu değildir. Çünkü "sahîh", usûl kitaplarında açıklandığı üzere, "sahih lizâtihî" ve "sahîh liğayrihî" olmak üzere iki kısma ayrılmaktadır. İbnü's-Salah'ın mâni gördüğü şey birinci kısımla ilgilidir. İkinci kısma gelince, bunda ne İbnü's-Salâh ne de diğerleri bir mani görmektedir. Nitekim Süyûtî, müteahhirinin sahih gördüğü hadisleri incelemiş ve bunların sahîh lizâtihî değil de sahîh liğayrihî türünde hadisler olduğunu görmüştür. Makalenin sonunda ise hadis tenkidi alanında yararlı olacağını düşünülen önemli sonuç ve tavsiyelere yer verilmiştir.

Anahtar Kelimeler: Hadis, hüküm, müteahhirîn, ehliyet, mütekaddimîn.

\section{The Capacity of Latecomers Critics of Hadith to Criticize the Hadith Between Theory and Practice}

\section{Abstract}

This is an article in the science of Hadith shed light on the eligibility of latecomers mohaddith - who came from after the fifth hijri century - in judging the Hadith.It explained that Ibn al-Salah is the first one talked about their eligibility and introduced his opinion about impossibility of their rules. Then it showed the different opinion which stated that it is possible to the latecomers who the eligibility is available for that.Then it showed evidence of Ibn al-Salah in the weakness of the eligibility of preceding Mohaddith for latecomers, and it supported this by the competence of the preceding Mohaddith in judging the narrators and submission of latecomers to them in this matter, and that the judgment on the Hadith is a branch of judging the narrator.Then it discussed the violators evidence in the light of variation between the two eligibilitie including shows variation including shows variation eligibility between preceding and latecomers Mohaddith, explaining the difference between 2 eligibilities which is manifested in four things: (a) scientific status (b) experience intellectual (c) 
201 | أهلية المتأخرين في الحكم على الحديث بين النظرية والتطبيق

different approach (d) external vulnerability like jurisprudential doctrine or other. Then it showed that the most correct in this matter is the opinion of Hafiz Suyuti it is no objection to Ibn al-Salah, because the sahih is two kind true to himself, true to others, as planned, in the book of the term, which prevented Ibn al-Salah is the first section only but the second section: he or anyone else does not prevent, and that Suyuti also examined what the latecomers corrected, and he found it followed the true to others not for its own sake. In conclusion I recorded the most important findings and recommendations that I've seen useful in monetary of Hadith.

Keywords: Hadith, critics of Hadith, latecomers mohaddith, eligibilitie, preceding mohaddith.

\section{أهلية المتأخرين في الحكم على الحديث بين النظرية والنطبيق}

الحمد الله وكفى، والصلاة على النبي المصطفى، وعلى آله وأصحابه ذوي القدر والجحاه والوفا، وعلى تابعيهم ومن بعدهم كمن لآثارهم اقتفى، وبعد:

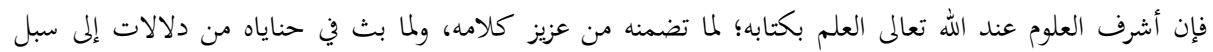

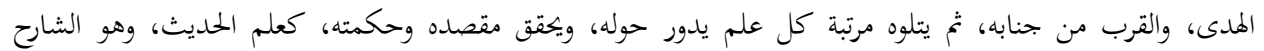

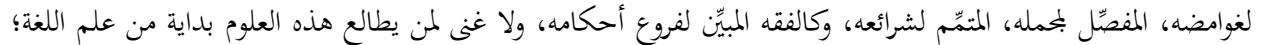

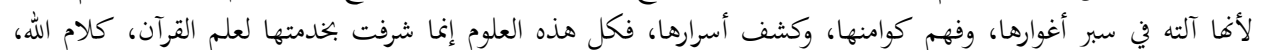
وأنعم به من شرف.

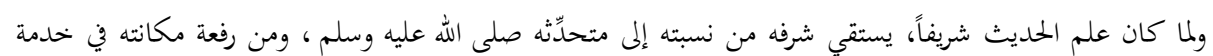

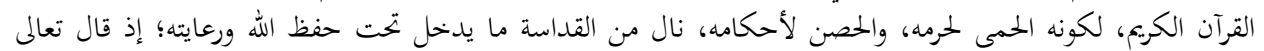

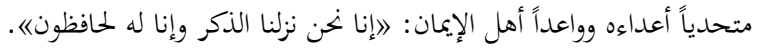

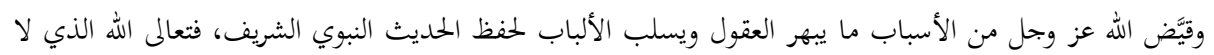

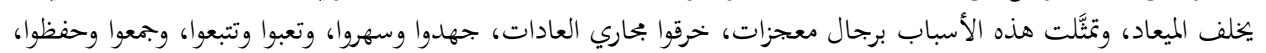

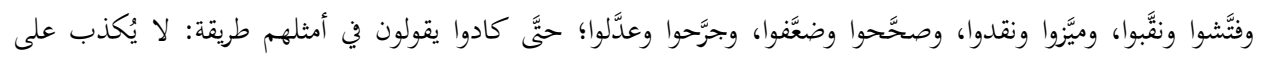

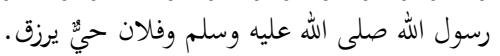

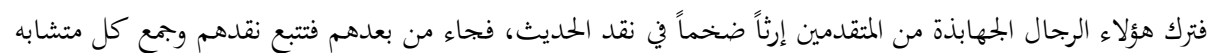

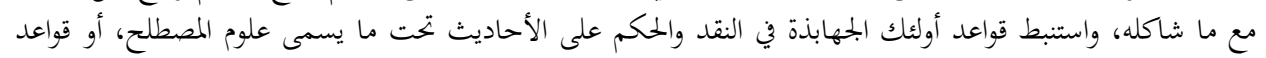
علم الحديث.

فهل كل من اطَّلع على تلك القواعد ووعاها هو قادر على بحاراة أولئك الرعيل في نقد الحديث والتصدر للتصحيح والتضعيف؟! من الناحية النظرية هذا ممكن، ولكن معلوم أن علم الحديث علم تطبيقي، سبق فيه تطبيقُ مفرداته تقعيدَ أصوله،

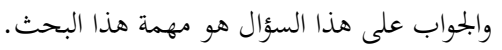


202 | Abdel Gani ADA

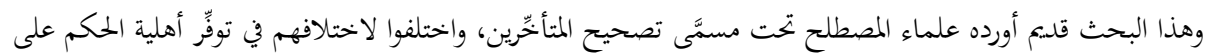
الحديث في العصور المتأخرة.

وسأتناول هذه المسألة في البحث وفق المرة.

1 - مأي ابن الصلاح في تعذر الحكم من المتأخر لتعذر توفر أهلية المتقدم فيه.

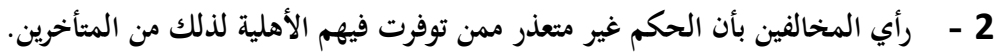

ويتفرع عن هذه المسألة ضعف أهلية المتأخرين بالنسبة للمتقدمين: وأذكر فيه: اختصاص المتقدمين في الحكم على الرواة ومنهجم فيه مع مثال تطبيقي، ثم خضوع المتأخرين لهم في هذه

الحكم على الحديث فرع عن الحكم على الراوي، وأذكر موقف المتأخرين منه على الصعيدين النظري والتطبيقي،

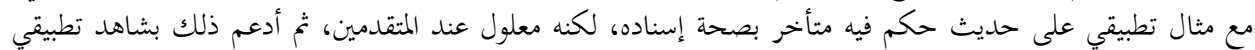

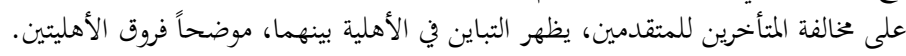

مناقشة أدلة المخالفين على ضوء تغاير الأهلية بين المتقدمين والمتأخرين.

$$
3 \text { - الراجح في المسألة ورأي الحافظ السيوطي }
$$

\section{مدخل إلى البحث:}

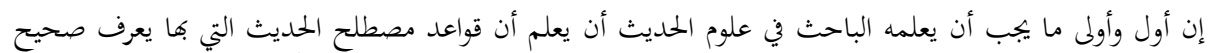

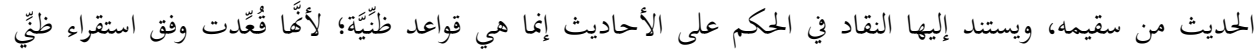

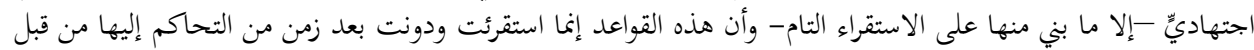

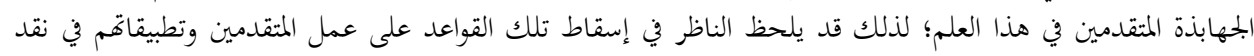
الأحاديث أموراً هامة منها:

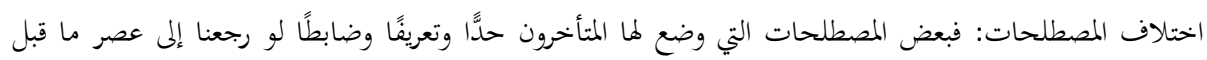

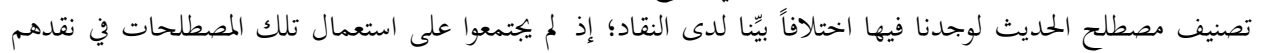

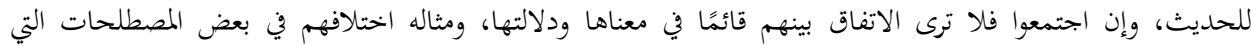

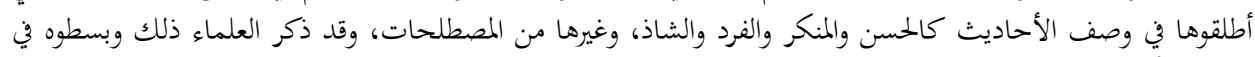
مؤلفاهیم (1)

وأيضاً يلحظ اختلاف المتقدمين في الحكم على الحديث الواحد، وهذا أكبر دليل على أن قواعدهم ظنية.

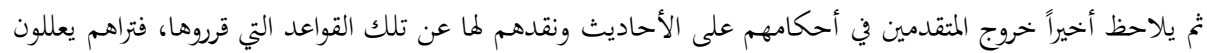

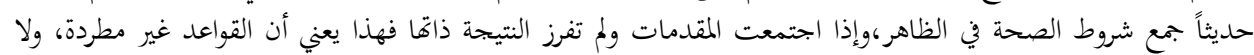




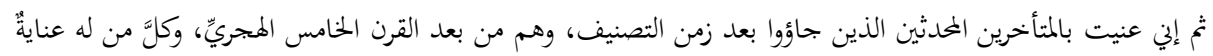

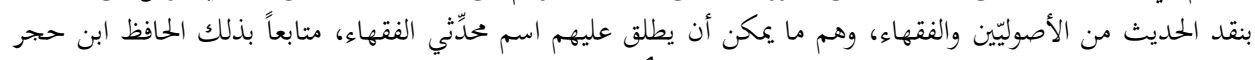

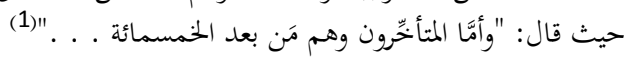

\section{رأي ابن الصلاح في مسألة تصحيح المتأخِّرين:}

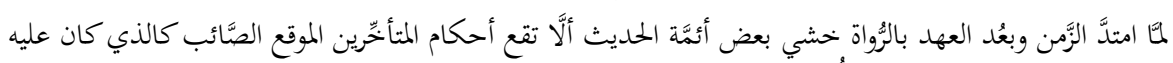

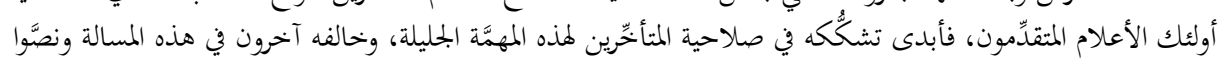

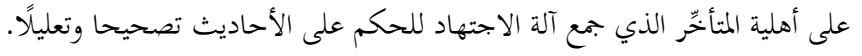

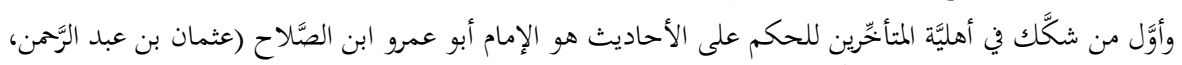

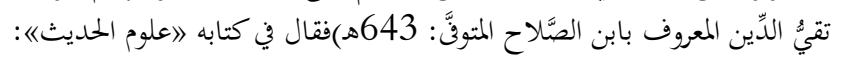

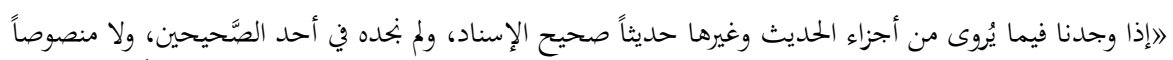

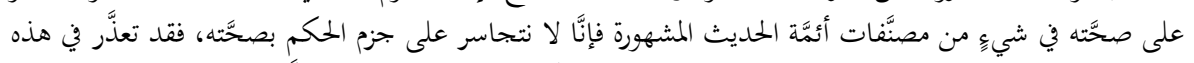

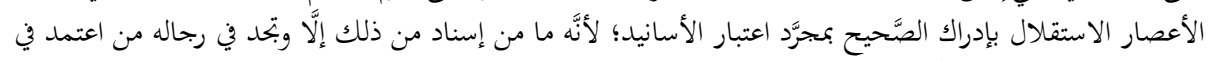

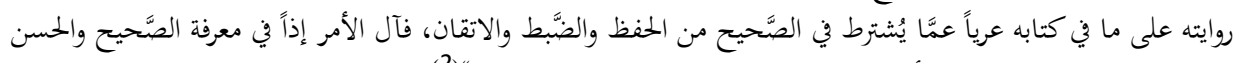

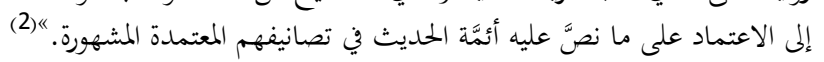

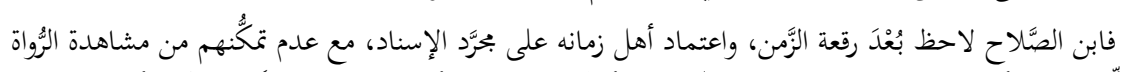

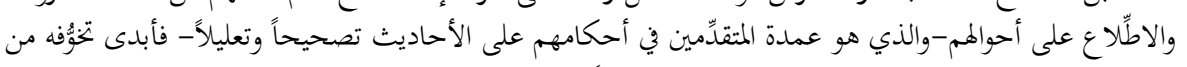

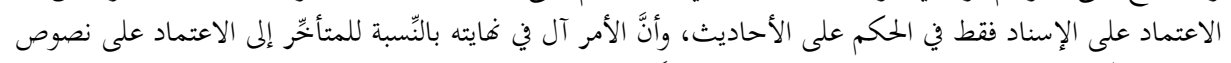

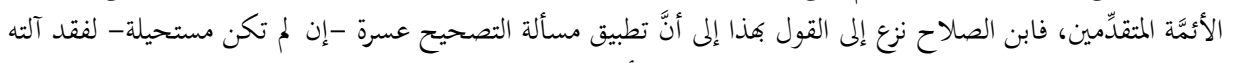

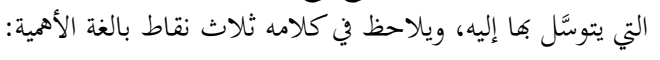

$$
\text { غير منصوص على تصحيحه من قبل المتقدمين من نقاد الإسناد. }
$$

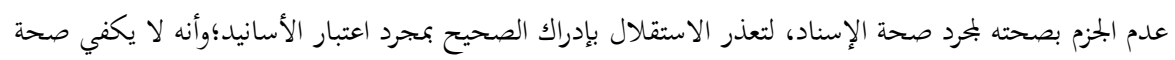
السند للقول بصحة الحديث.

رأي المخالفين:

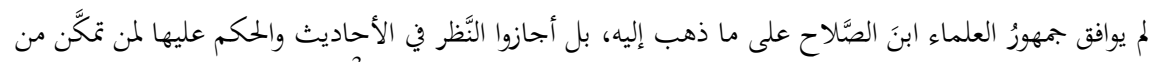

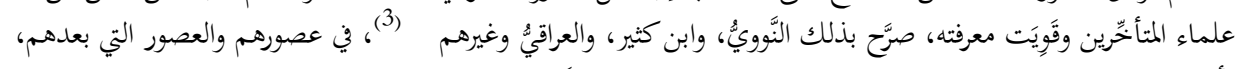

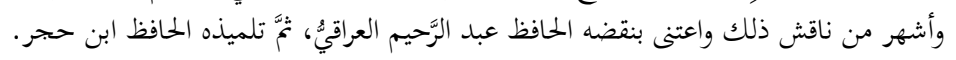

(1) النّكت على كتاب ابن الصّّلاح 586/2. تحقيق: ربيع بن هادي عمير المدخلي، الناشر عمادة البحث العلمي بالجامعة الإسلامية، المدينة المنورة، ط 1، 1404هـ.

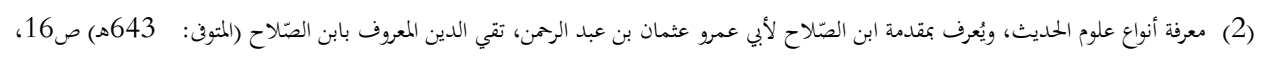

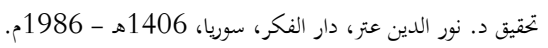

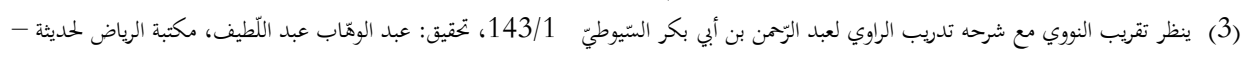

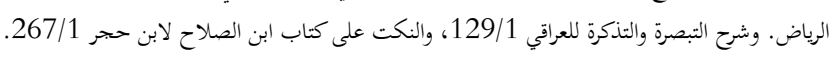




\section{4 | Abdel Gani ADA}

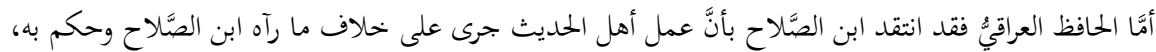

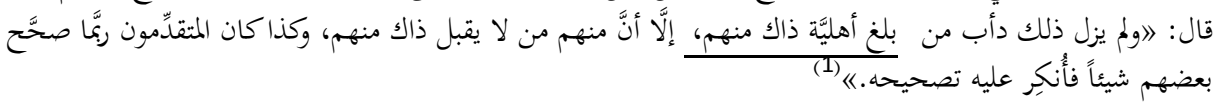

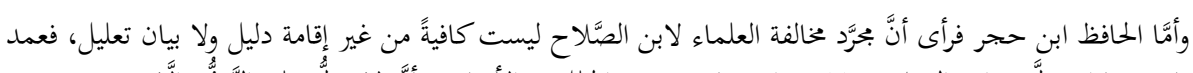

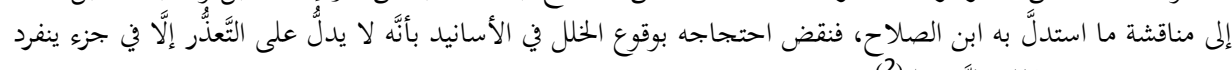
بروايته من وُصِف بذلكَ ماست التَّساهل (2).

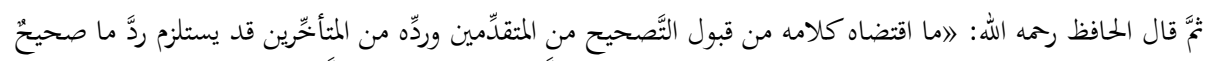

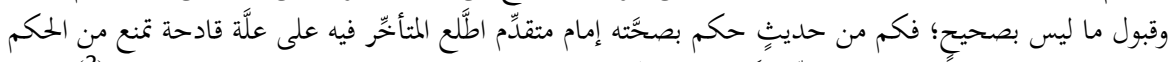

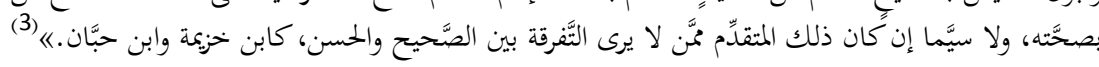

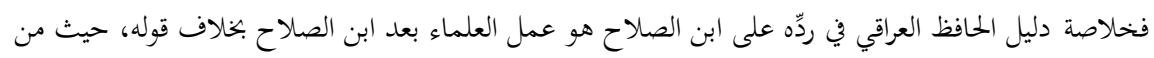

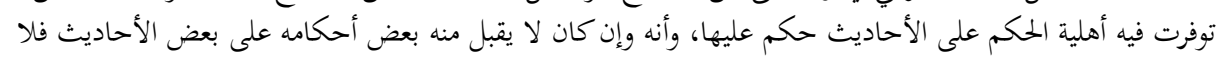

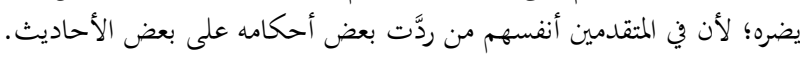

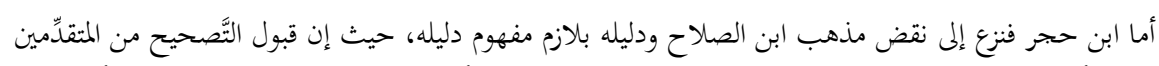

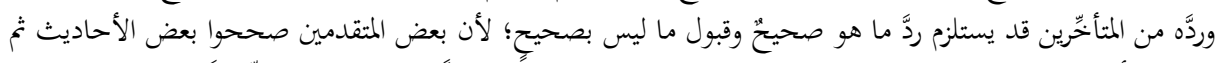

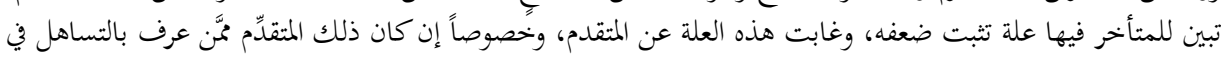

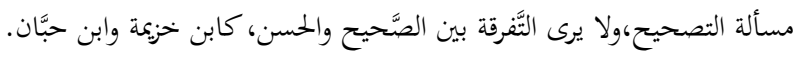

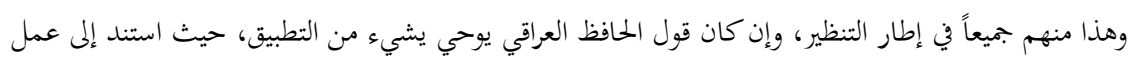

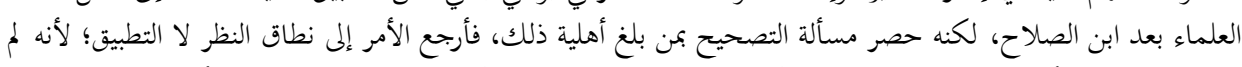

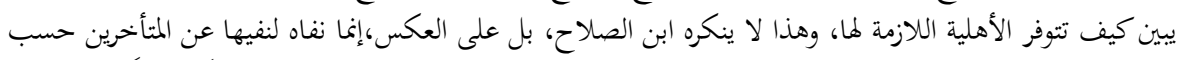

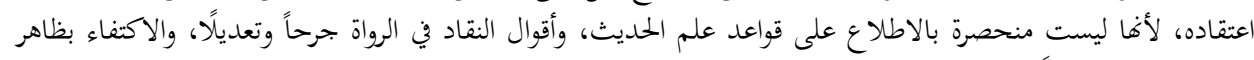

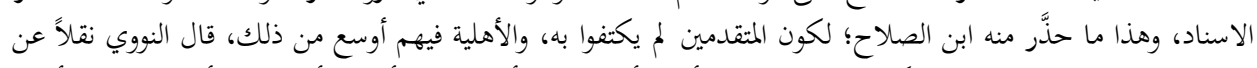

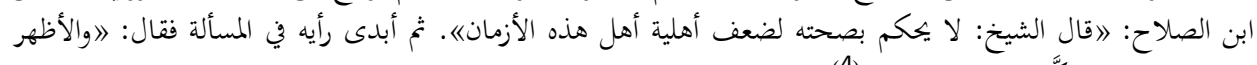

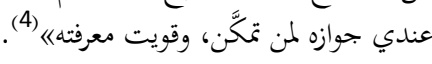

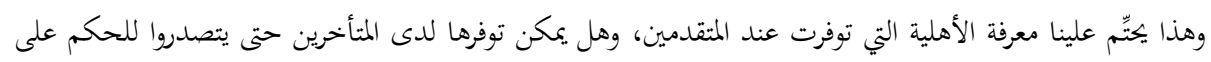
الرواة والأحاديث، ومدى إمكانية تطبيقه في الواقع.

\section{اختصاص المتقدمين في الحكم على الراوي:}

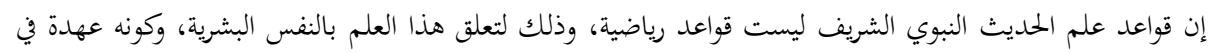

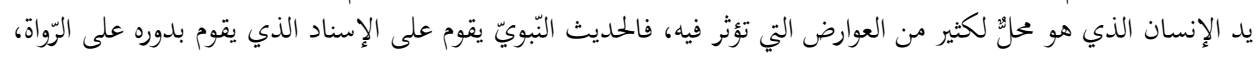

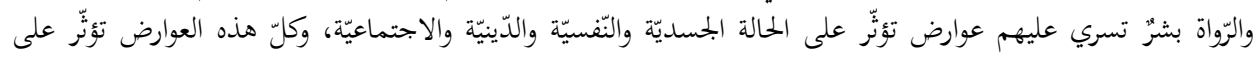

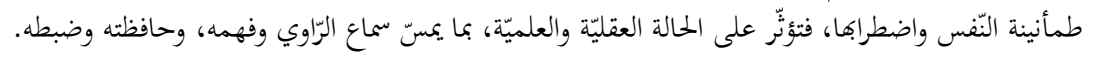

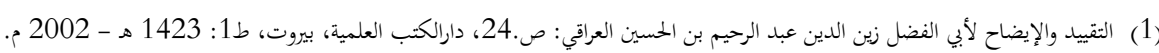

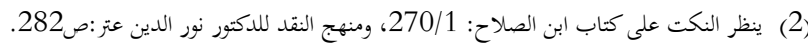

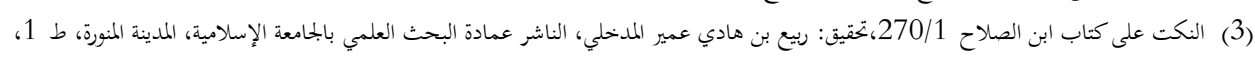

1404هـ وينظر تدريب الراوي: 147/1 الرياح

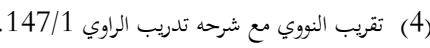


205 | أهلية المتأخرين في الحكم على الحديث بين النظرية والتطبيق

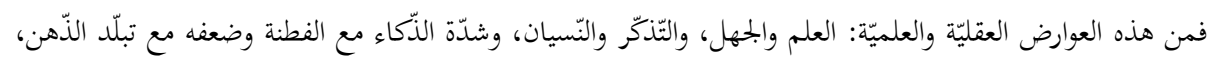

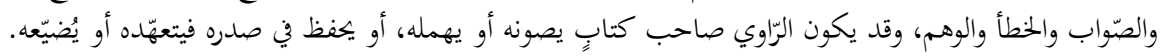

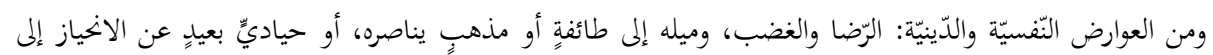

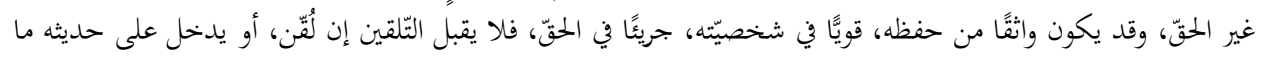

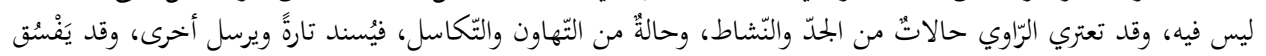

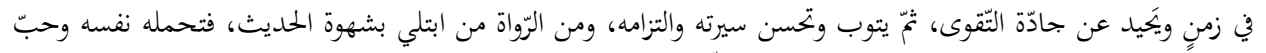

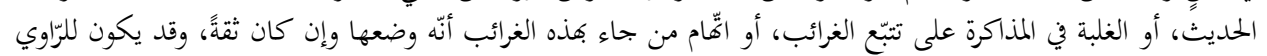

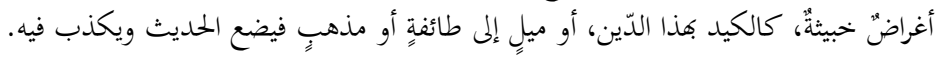

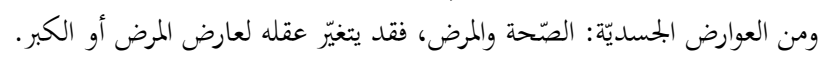

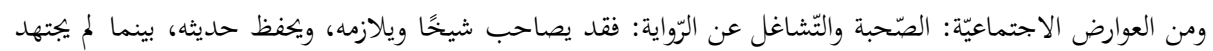

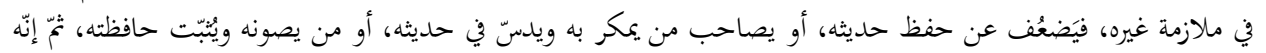

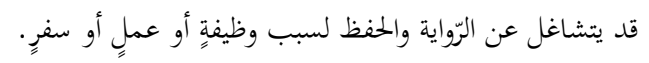

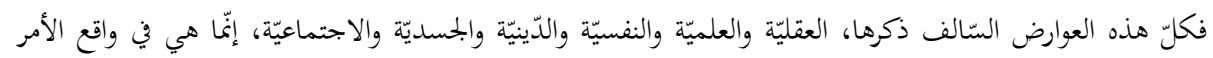

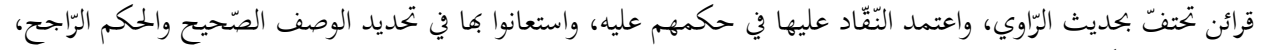
تجريمًا أو تعديلاً.

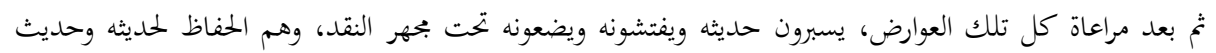

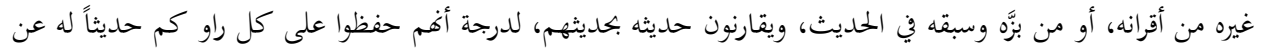

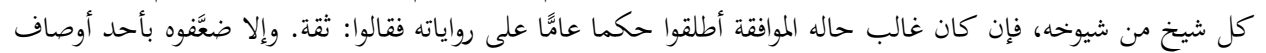

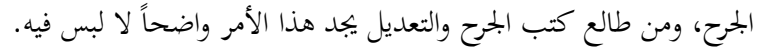
مثال تطبيقي على منهج المتقدمين في الحكم على الراوي:

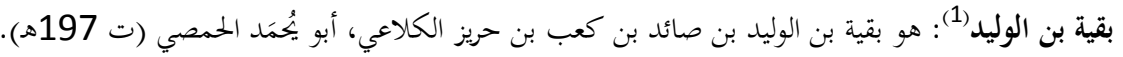

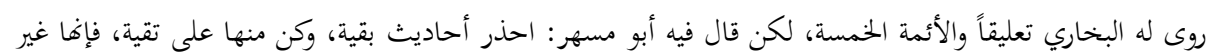

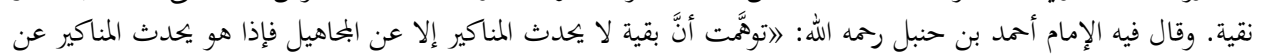

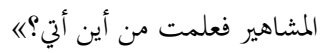

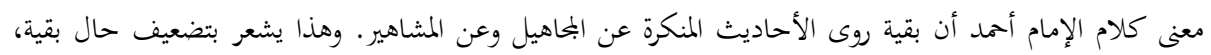

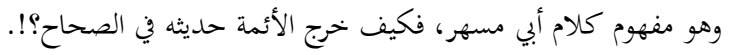

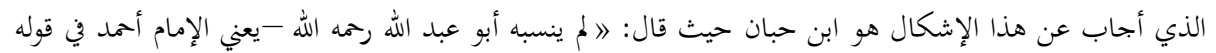

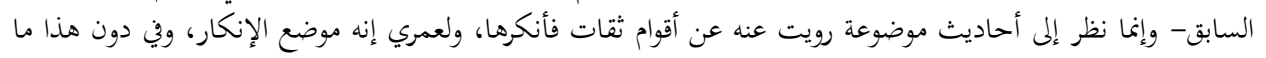

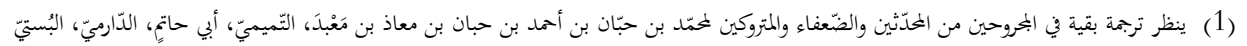

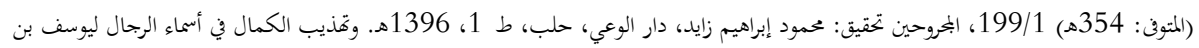

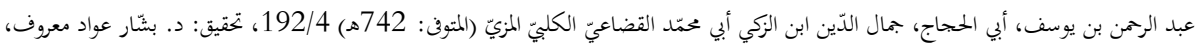

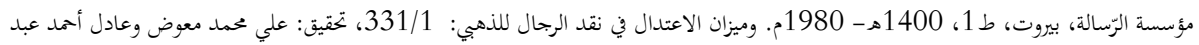

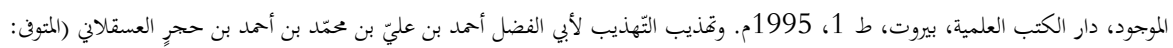

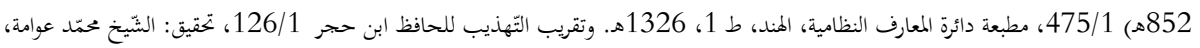

دار الرّشيد، حلب، ط1، 1406، 1406هـ مطبعة دائرة المعاف 


\section{6 | Abdel Gani ADA}

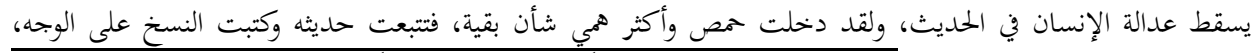

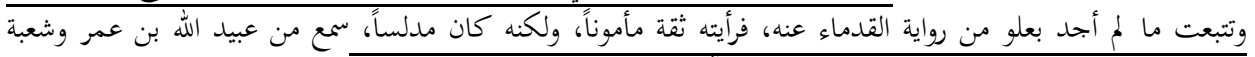

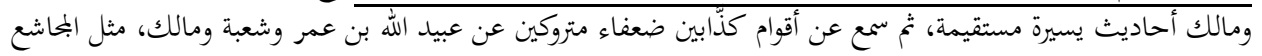

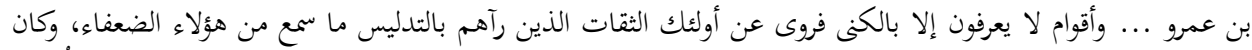

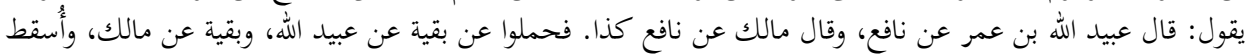

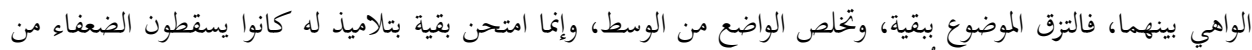

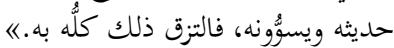

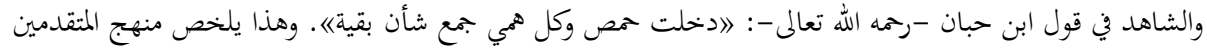

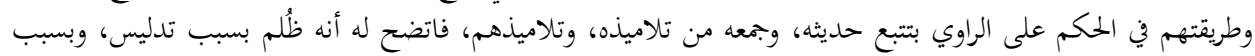

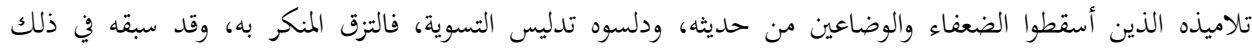

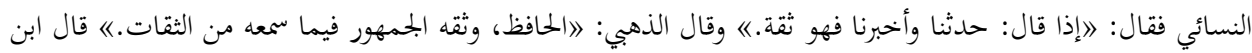

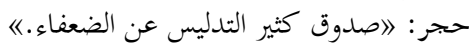

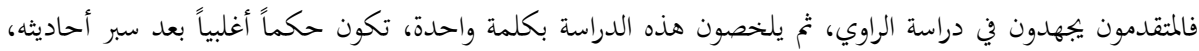

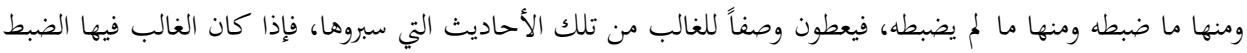

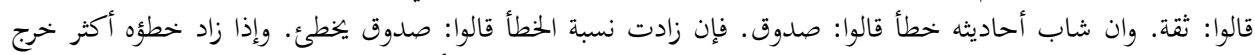

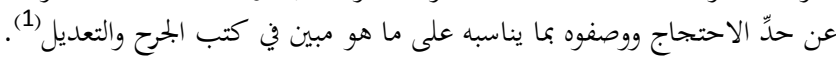

\section{خضوع المتأخرين للمتقدمين في الحكم على الرواة:}

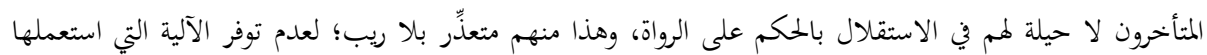

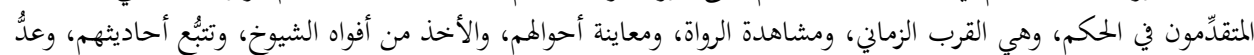

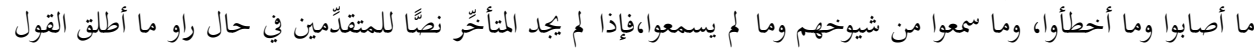

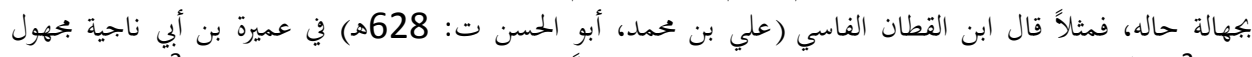

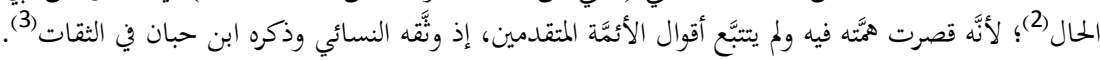

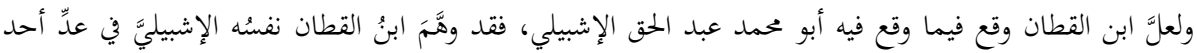

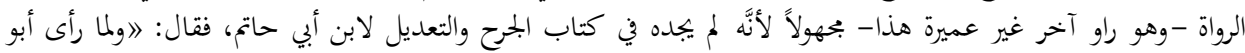

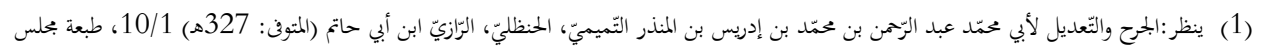

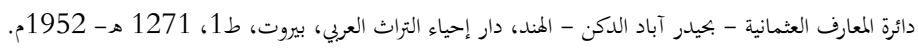

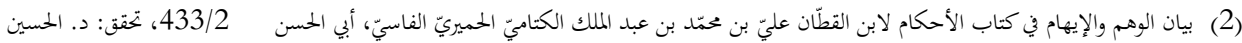

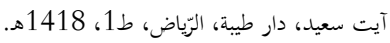

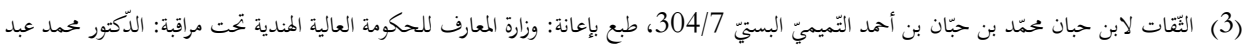

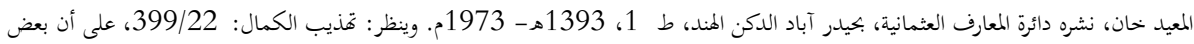

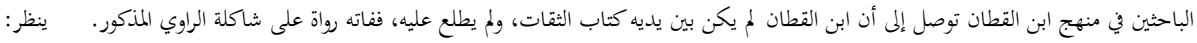
Hüseyin Akgün, Mağribli Muhaddis İbnü'l-Kattân'ın Hadis Anlayışı (Ankara: Gece Kitaplığı Yayınları, 2014), 131. 
207 | أهلية المتأخرين في الحكم على الحديث بين النظرية والتطبيق

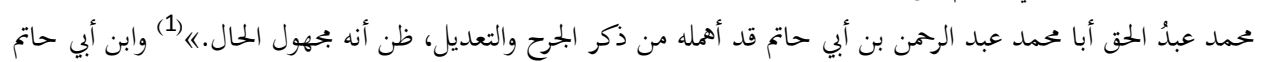

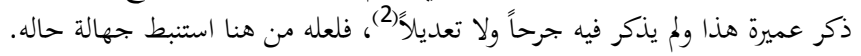

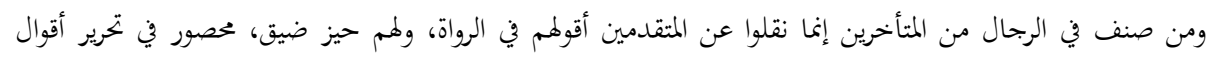

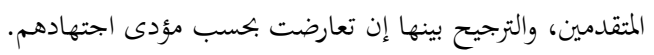

\section{الحكم على الحديث فرع عن الحكم على الراوي:}

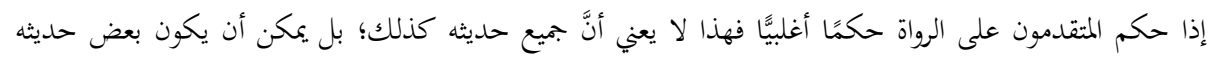

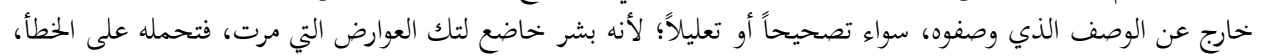

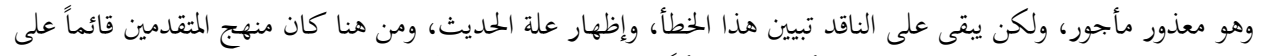

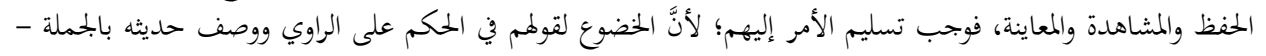

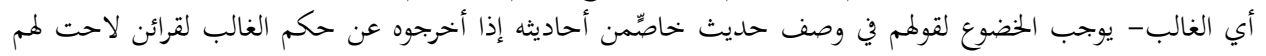

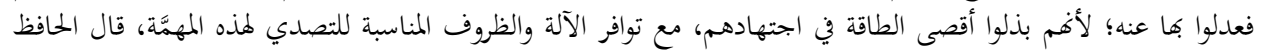

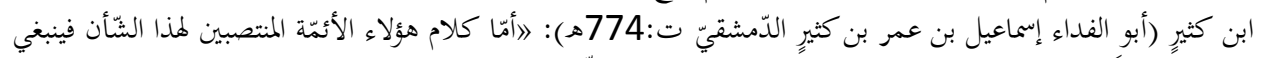

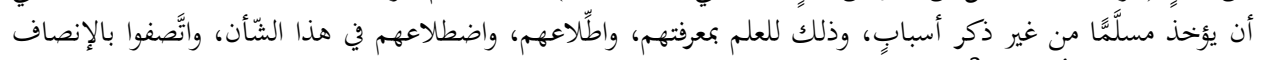

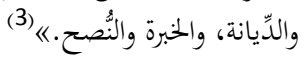

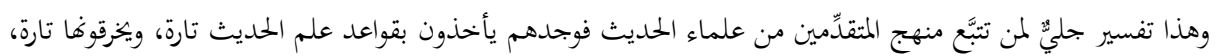

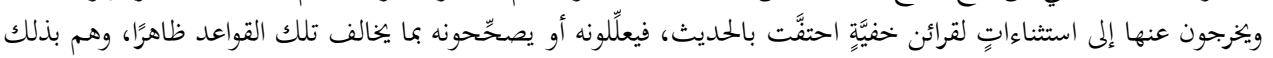

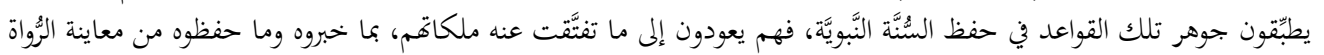

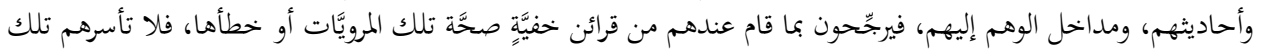

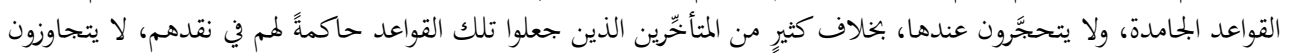

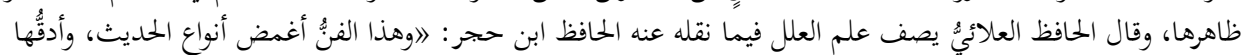

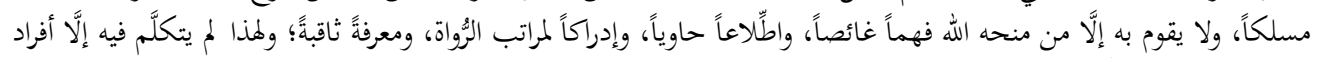

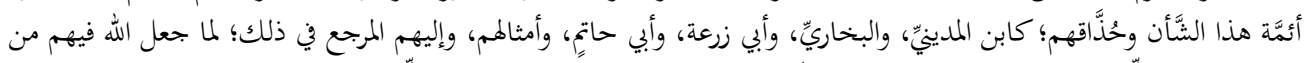

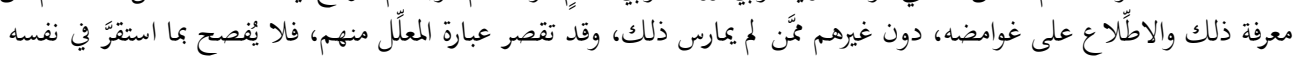

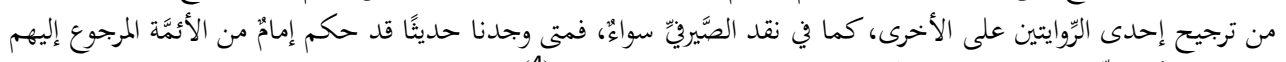

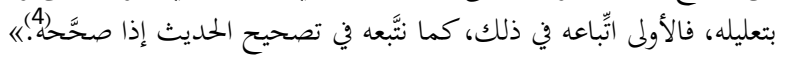

\section{موقف المتأخرين من الحكم على الحديث:}

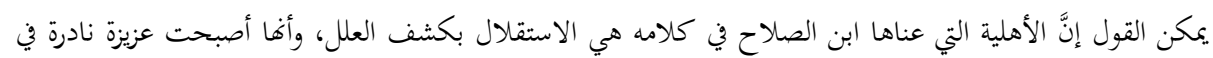

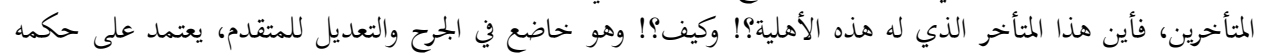

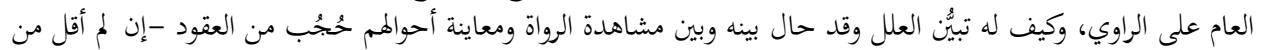

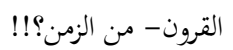

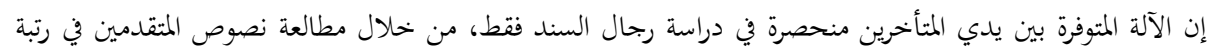

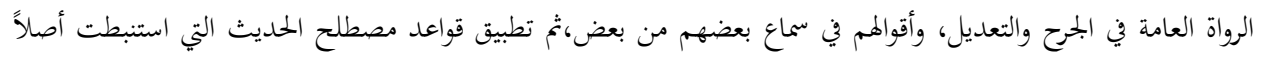

$$
\begin{aligned}
& \text { (1) بيان الوهم والإيهام: 134/2. }
\end{aligned}
$$

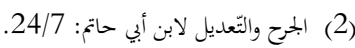

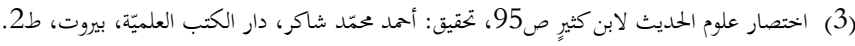

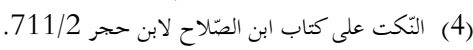




\section{8 | Abdel Gani ADA}

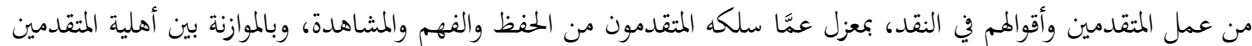

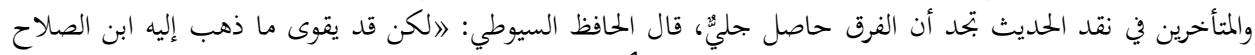

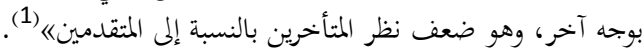

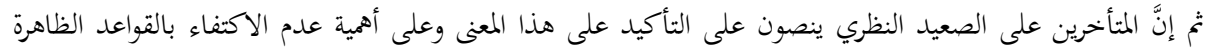

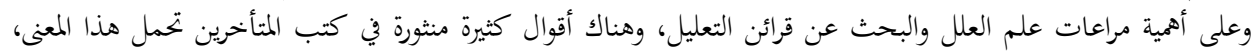

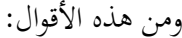

- ابن دقيق العيد (أبو الفتح محمد بن علي بن وهب بن مإن مطيع القشيري، ت:

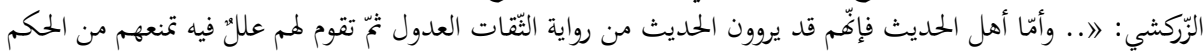

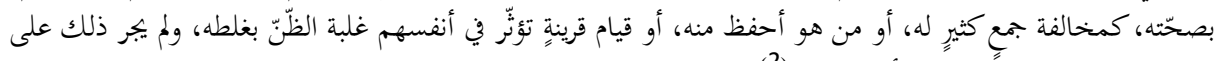

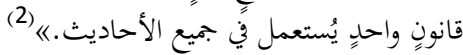

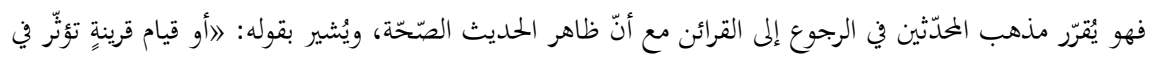

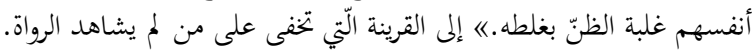

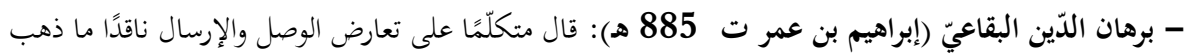

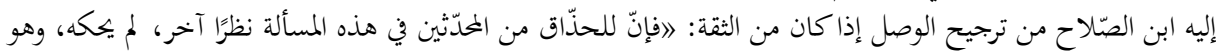

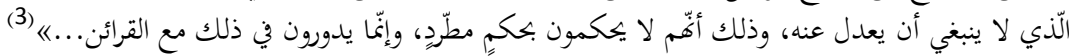

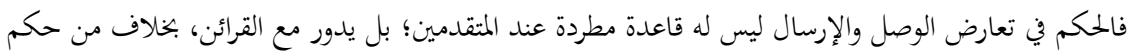
بصحة الزيادة من الثقة مطلقاً من المتأخرين.

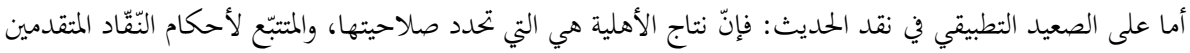

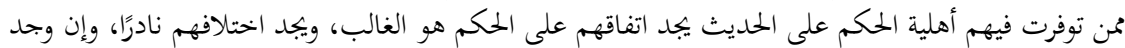

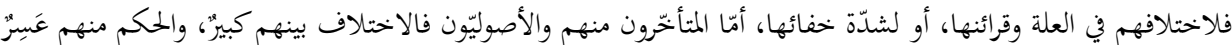

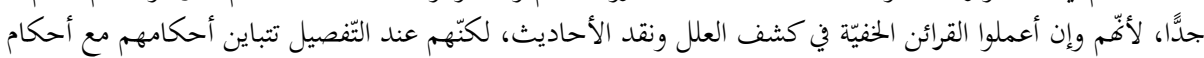

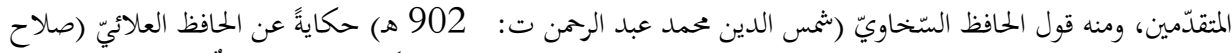

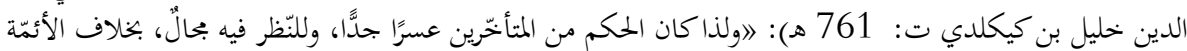

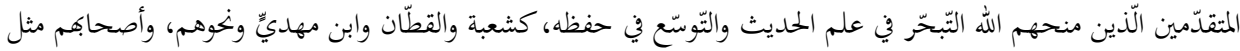

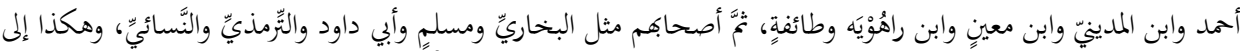

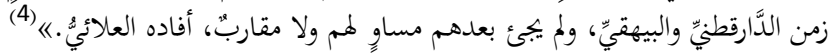

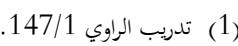

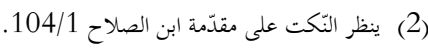
(3) النكت الوفية بما في شرح الألفية لبرهان الدين إبراهيم بن عمر البقاعي 426/1، تعقيق: ماهر ياسين الفحل، مكتبة الرشد ناشرون، ط1، 1428 هـ.

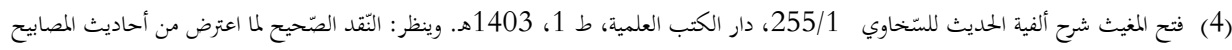

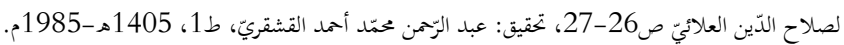

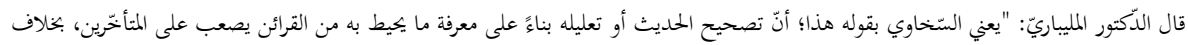

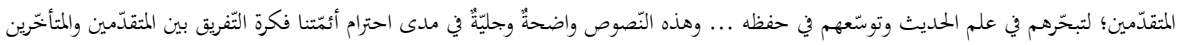

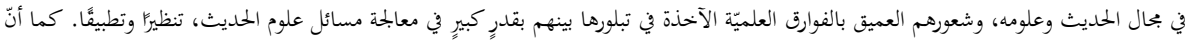

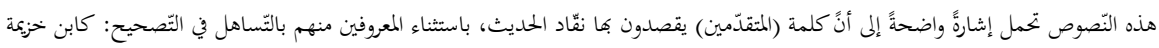


209 | أهلية المتأخرين في الحكم على الحديث بين النظرية والتطبيق

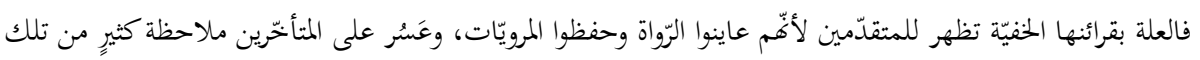

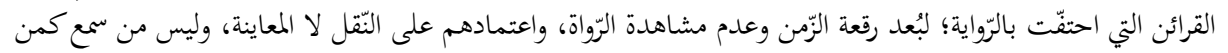

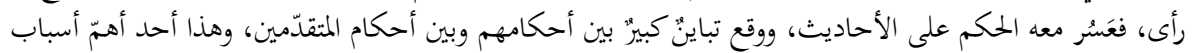

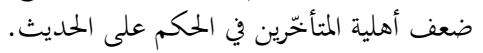

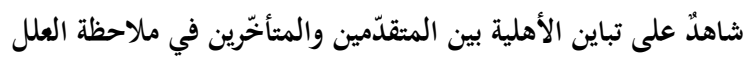

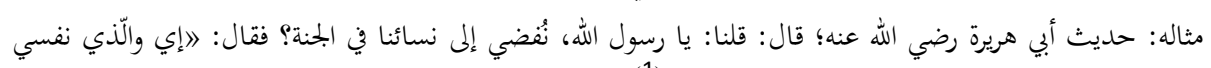

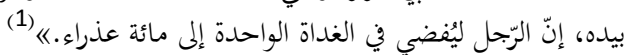

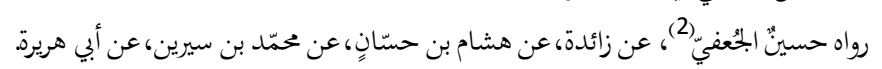

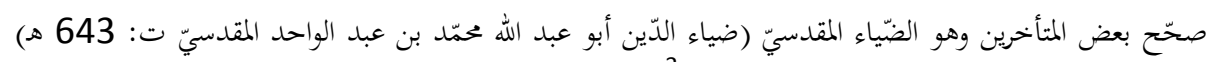

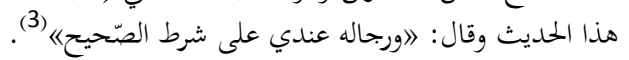

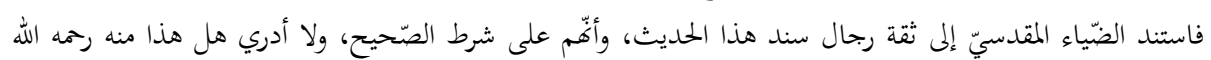

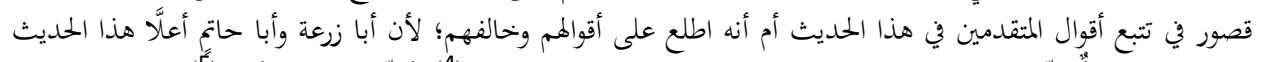

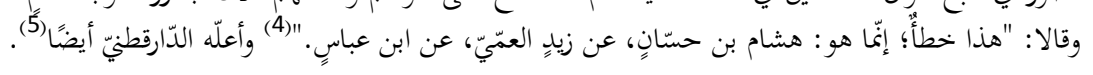

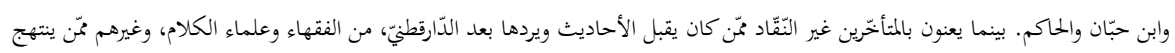

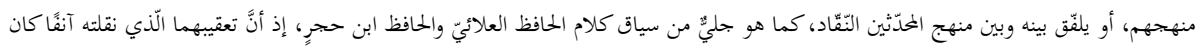

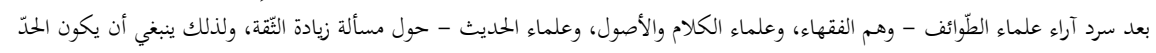

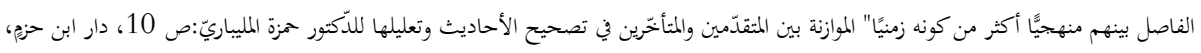
بيروت، ط2 2001، 2001م.

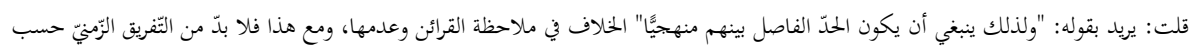

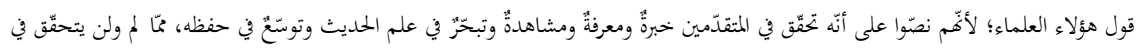

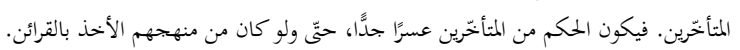

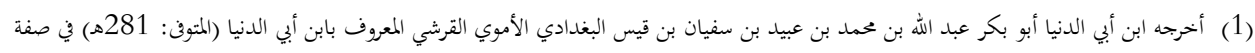

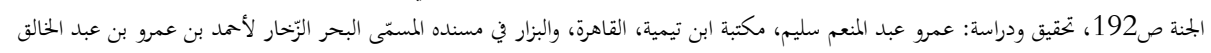

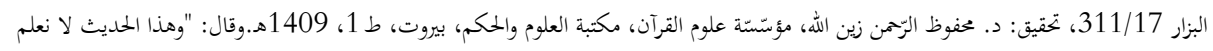

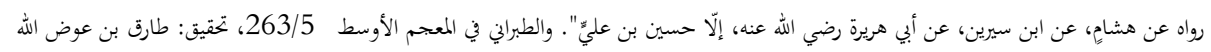

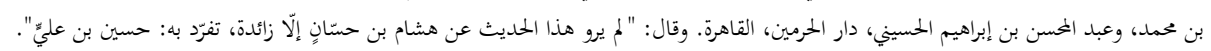

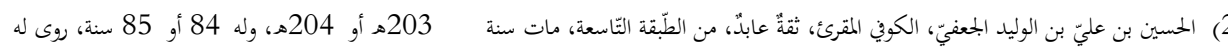

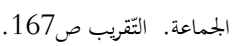

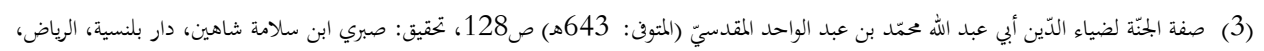
2002- 1423، 1423.

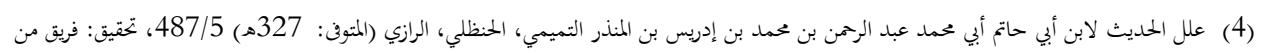

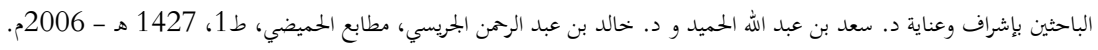

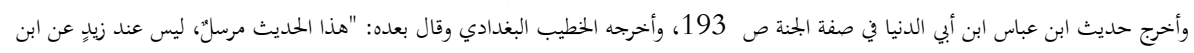

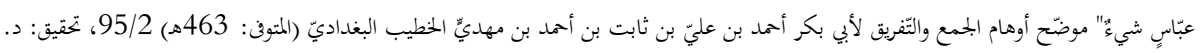

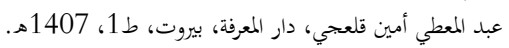

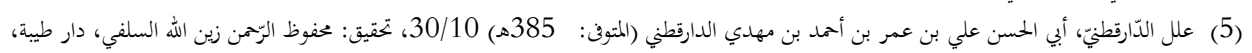

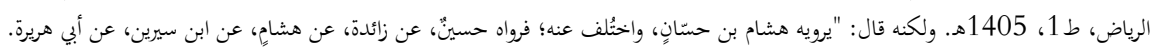


210 | Abdel Gani ADA

ونصّ أبو حاتمٍ على أنّ الواهم فيه هو حسينٌ الجعفيّ. (1)

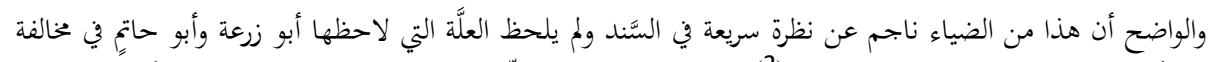

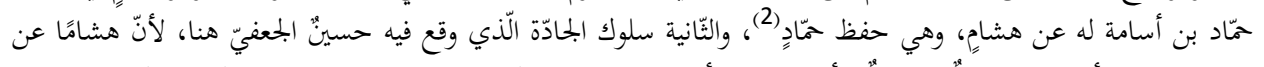

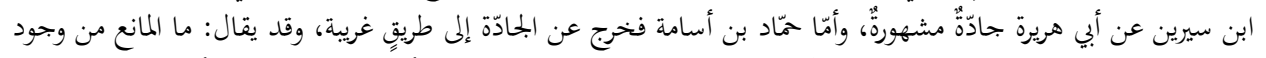

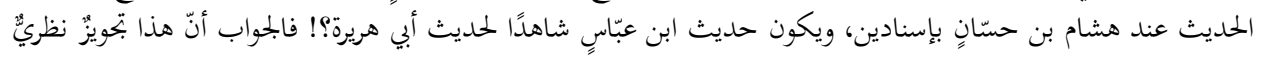

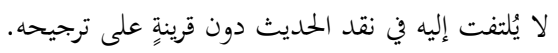

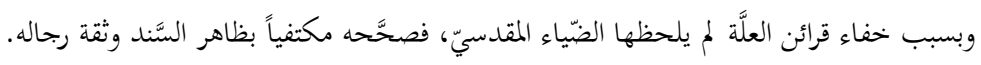

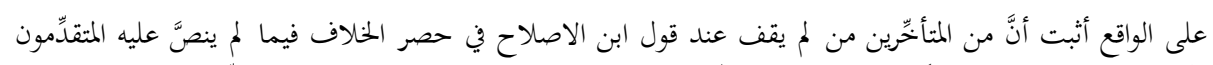

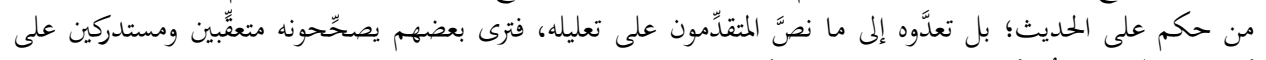

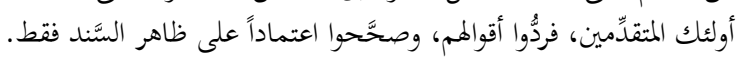

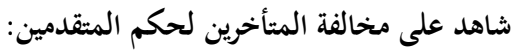

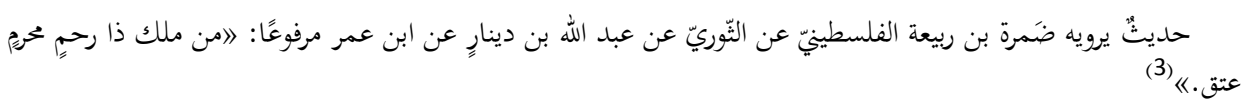

أعلّ هذا الحديث من المحدّثين: أحمد والتّرمذيّ والنّائيّ والبيهقيّ.

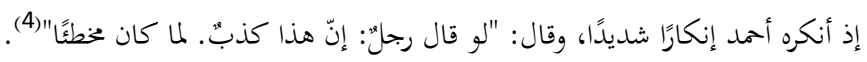

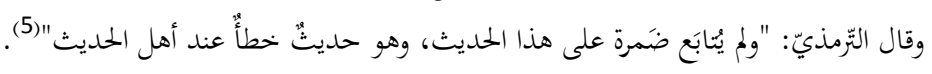

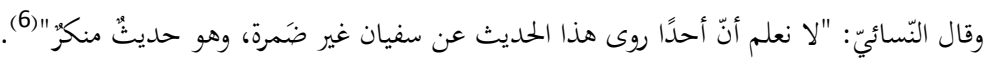

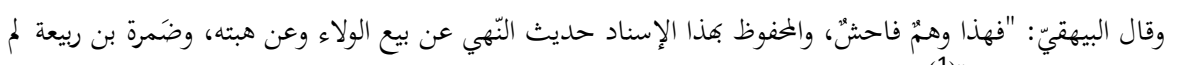

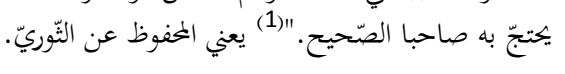

وخالفه ابن أسامة؛ فرواه عن هشامٍ، عن ابن سيرين أنّه قال ذلك عن ابن عبّاسٍ؛ وهو أشبه بالصواب." وقد تقدّم أن أبا زرعة وأبا حاتِّ قالا في رواية

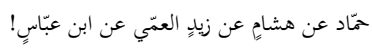
487/5 (1) ملل الحمديث.

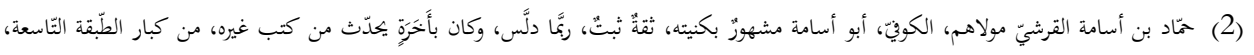

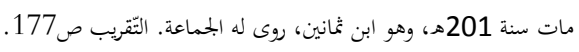

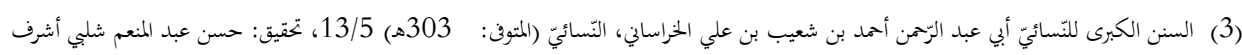

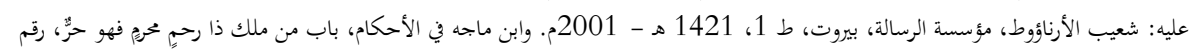

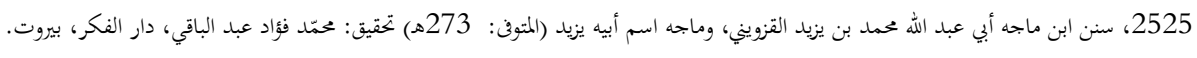

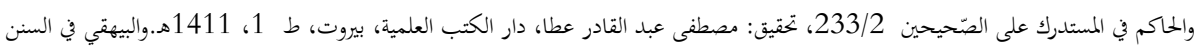

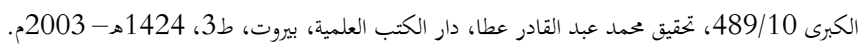

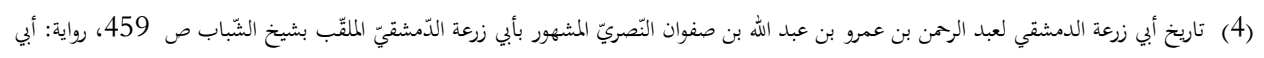

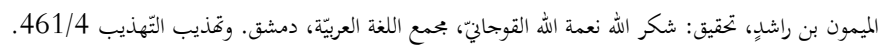

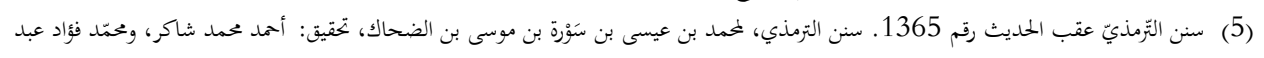

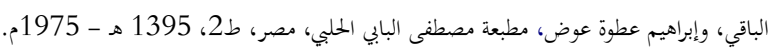

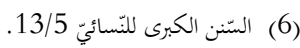

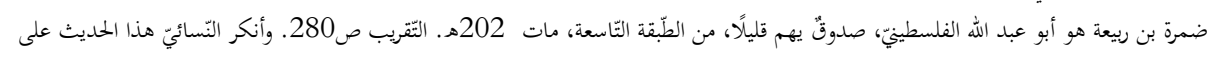

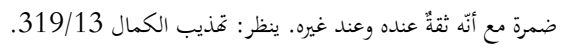


211 | أهلية المتأخرين في الحكم على الحديث بين النظرية والتطبيق

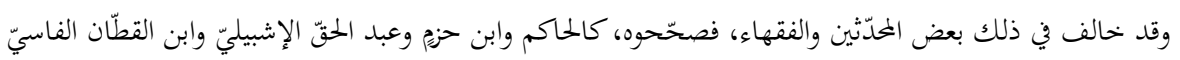

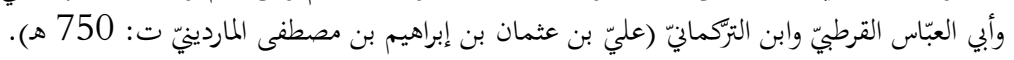

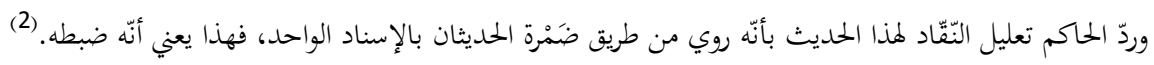

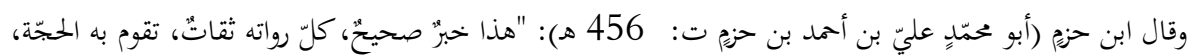

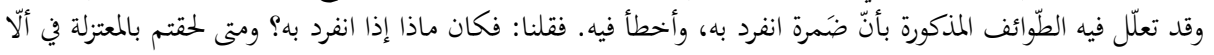

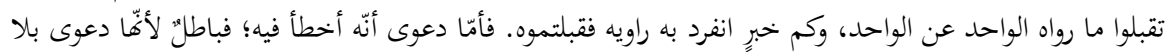
برهانٍ. "(3)

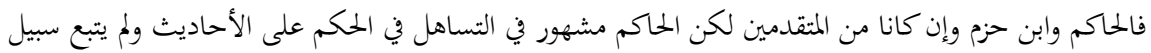

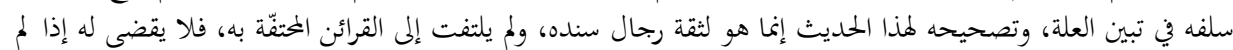

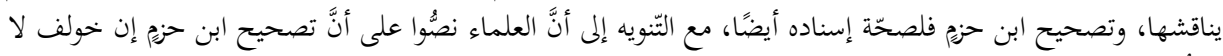

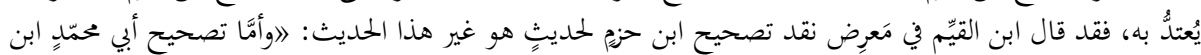

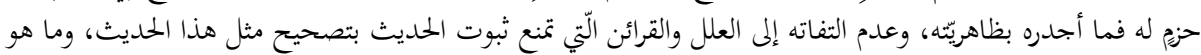

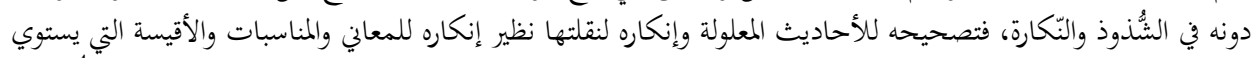

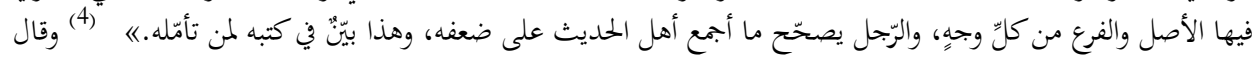

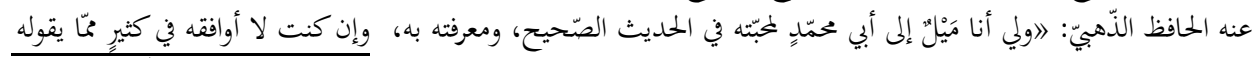

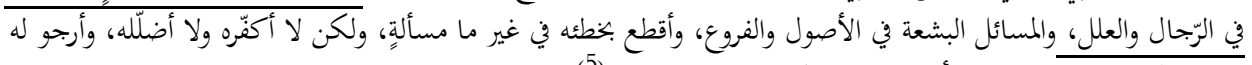

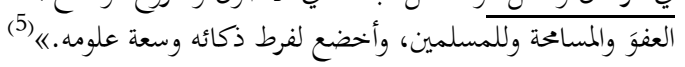

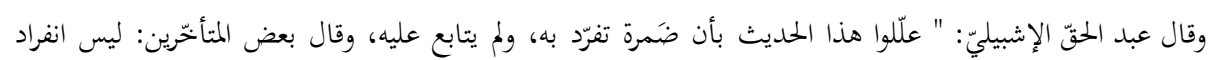

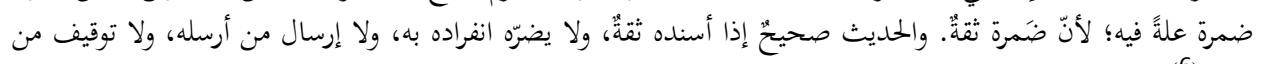
وقفه"). (6).

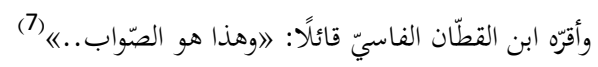

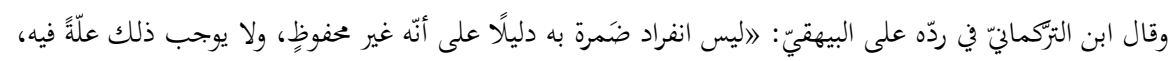

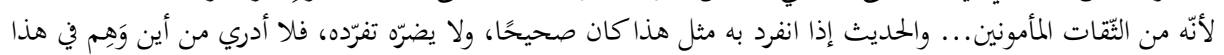
الحديث راويه ؟!)

(1) معرفة السنن والآثار لأبي بكر البيهقي أممد بن الحسين بن علي بن موسى 407/14، تعقيق: عبد المعطي أمين قلعجي، دار قتيبة، دمشق، ط 14، 1412هـ

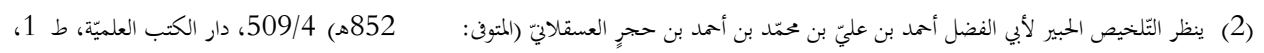
1419هـ

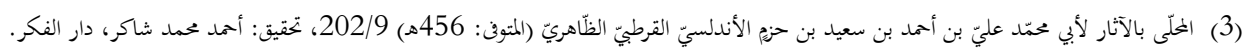

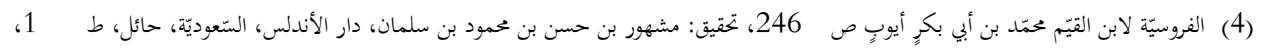
1414هـ

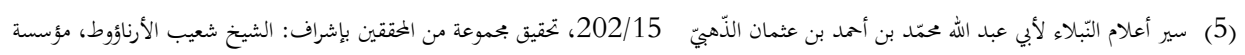

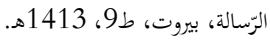

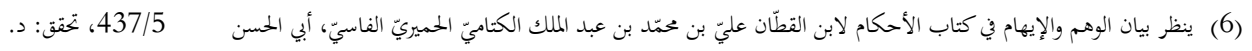

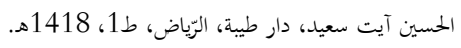
(7) المرجع السّابق. 


\section{2 | Abdel Gani ADA}

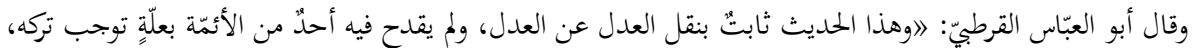

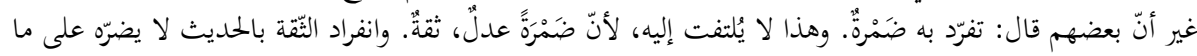

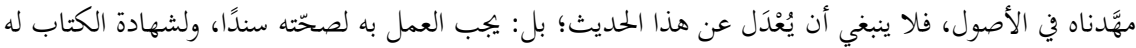
(2)

فأشار إلى صحّة السّند، وثقة رجاله، وصحّة المعنى وموافقته للشّرع، ولم يلتفت إلى غير ذلك من القرائن التّي احتفت به.

1 - 1 أدلة المصحّحين.

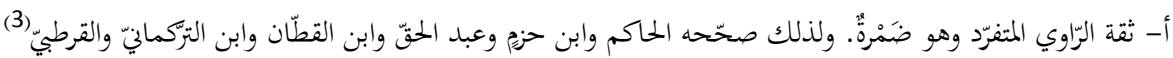

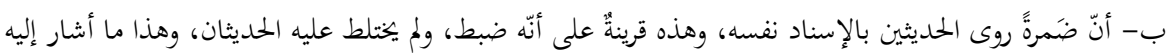

\section{ج- صحّة معنى المتن وموافقته للشّرع، كما نصّ على ذلك القرطبي.

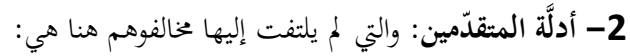

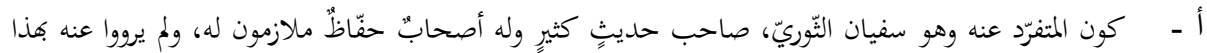

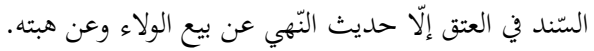

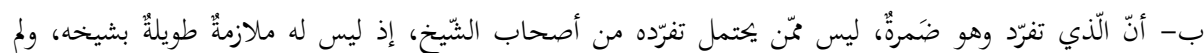

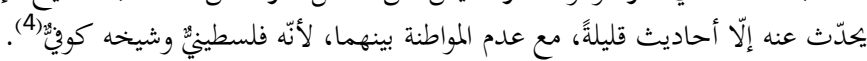

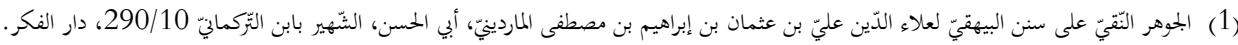

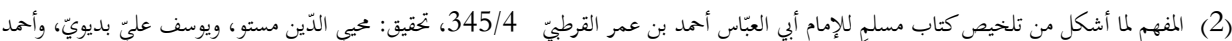

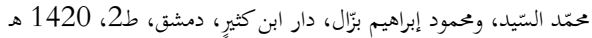

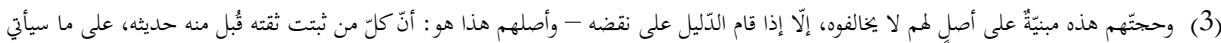

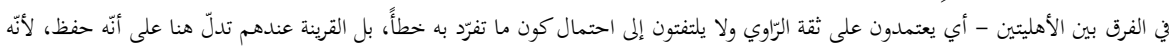
كما أشار الحاكم بأنه روي من طريق ضمرة الحديثان بالإسناد الواحد.

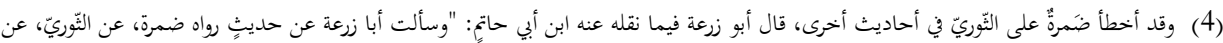

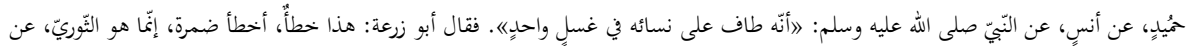

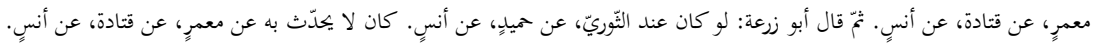

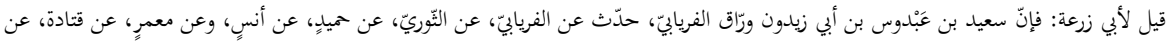
قال: ما أدري ما هذا؟ ما أعرف من حديث الفريابِّيَ إلّا عن الثّوريّ، عن أبي عروة، عن أبي الخطّاب، عن أنسِ، ما أدري ما هذ؟" علل الحديث

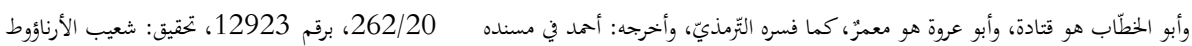

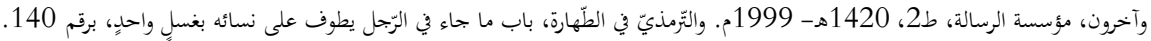

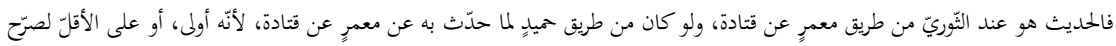

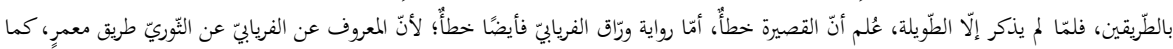

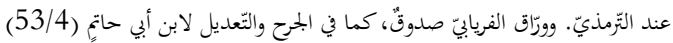

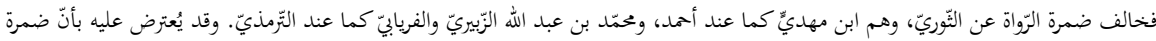

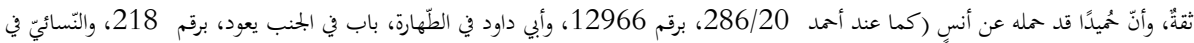

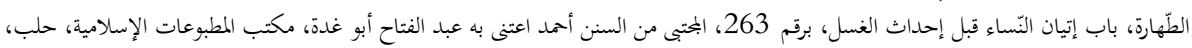


213 | أهلية المتأخرين في الحكم على الحديث بين النظرية والتطبيق

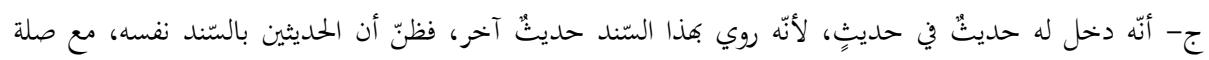

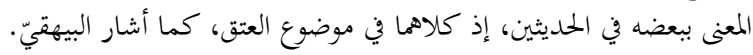

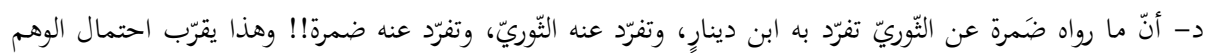

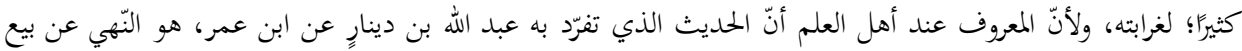

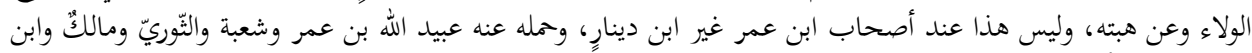
عيينة وغيرهم (1). ولذلك أعلّه أحمد والتّرمذيّ والنّسائيّ والبيهقيّ.

3- مناقشة أدلَّة التّصحيح:

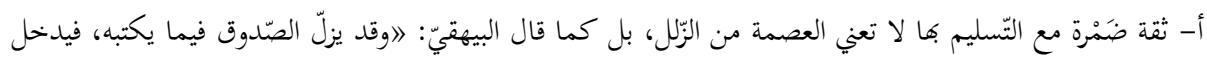

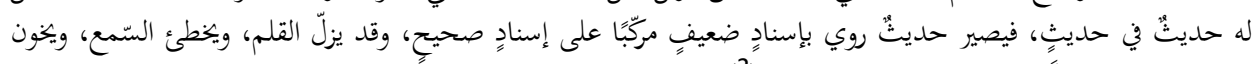

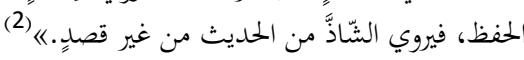
أضف إلى ذلك أنّه وإن كانت رتبة ضمرة التّوثيق، لكنّه في الثّوريّ هناك من هم أوثق منه، لطول ملازمتهم له، ولم

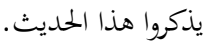

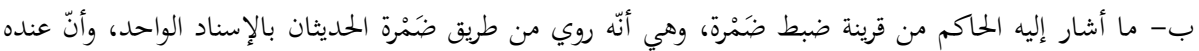

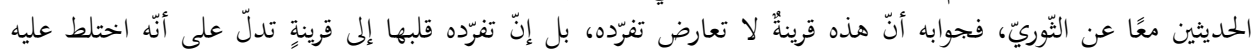

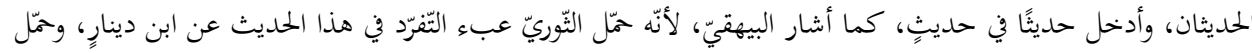

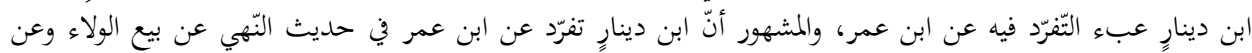

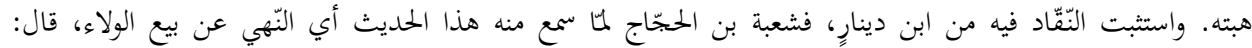

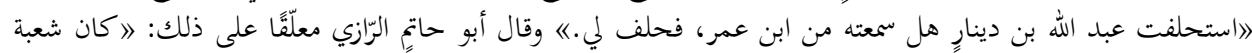

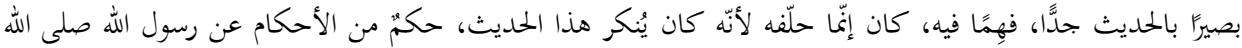

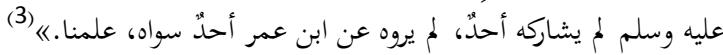

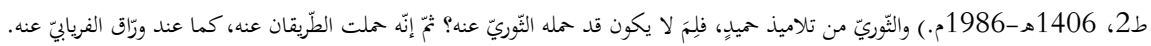

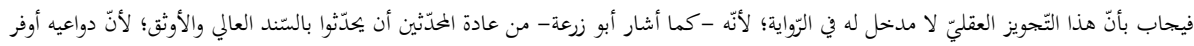

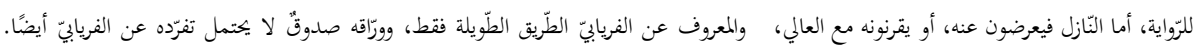

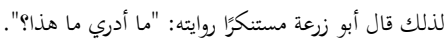

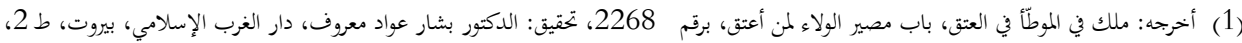

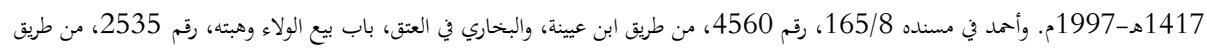

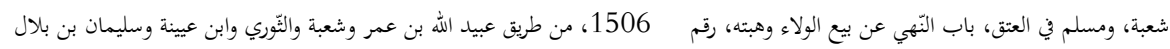

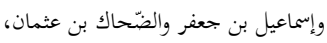

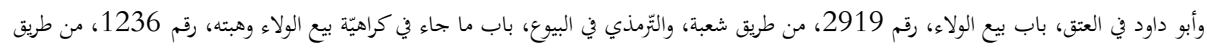

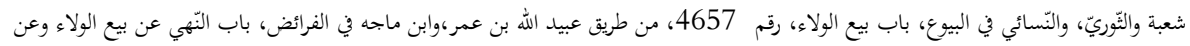
هبته، رقم 2747، من طريق شعبة والثوري.

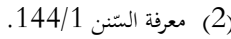

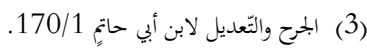

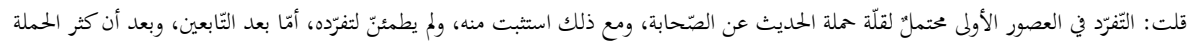

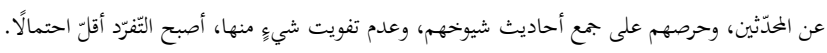




\section{4 | Abdel Gani ADA}

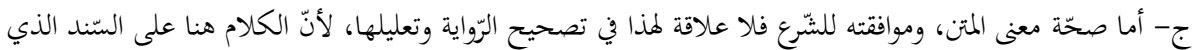

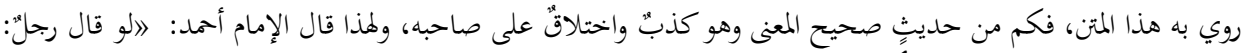

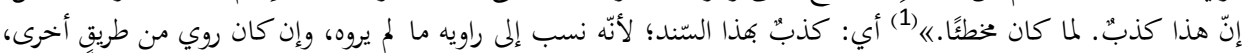
ولا عبرة لصحّة المتن في هذا. كلمان.

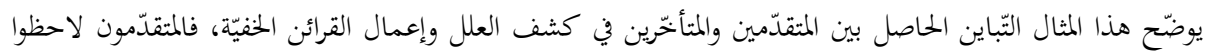

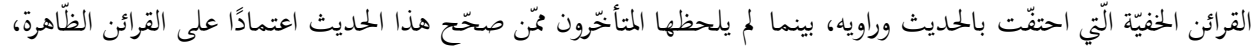

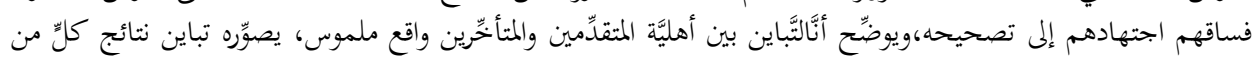

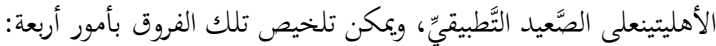

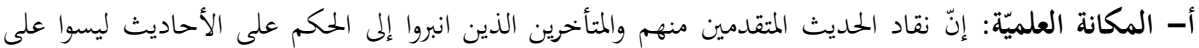

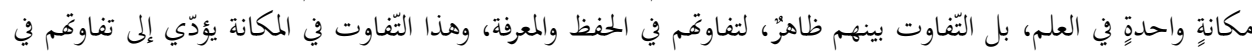

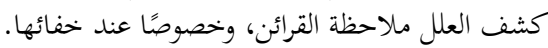

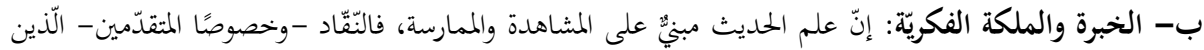

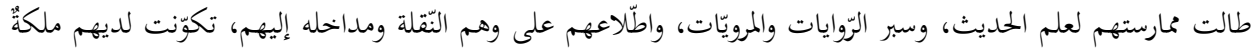

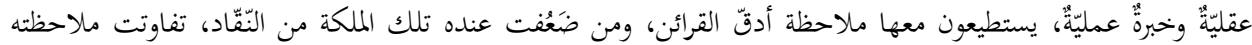

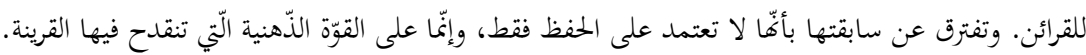

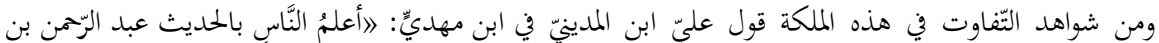

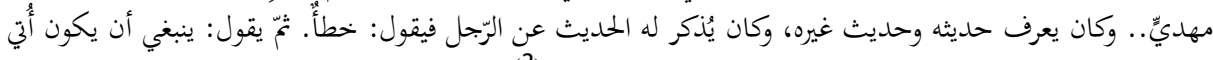

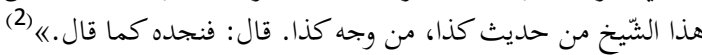

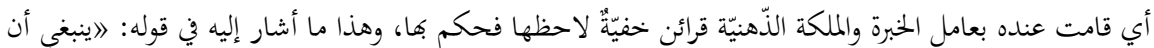

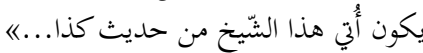

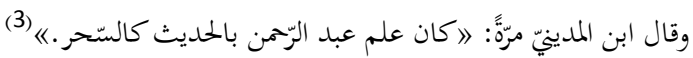

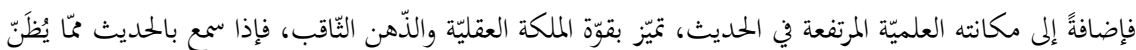

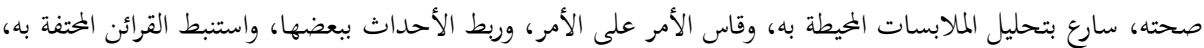

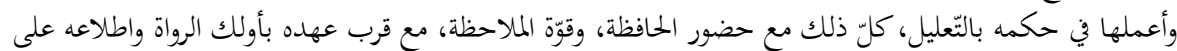

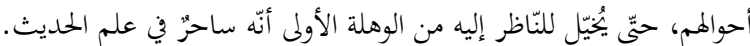

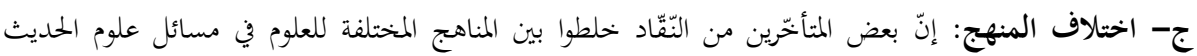

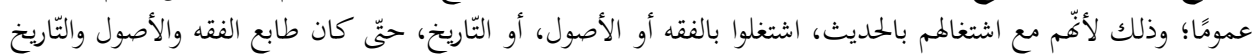

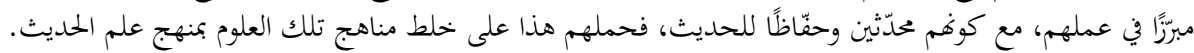

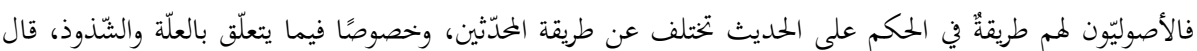

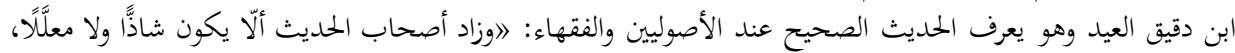

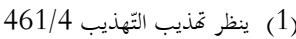

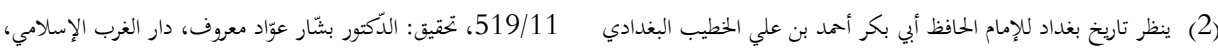

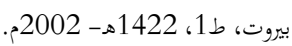

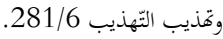

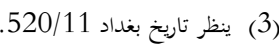




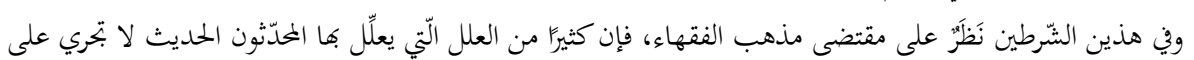
أصول الفقهاء.《)

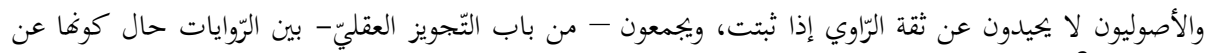

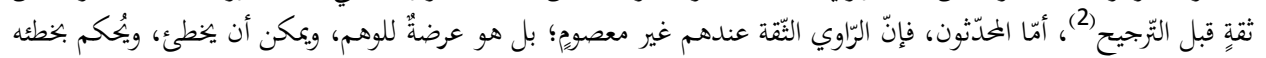

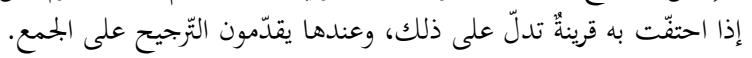

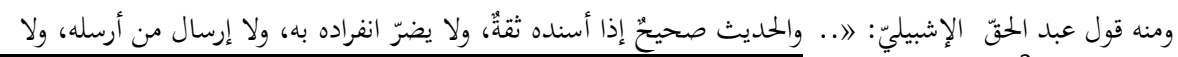
توقيف من وقفه.《(3) وقول ابن دقيق العيد فيمن اضطرب في السّند بين راويين: الفإِن كانا ثقتين فهاهنا مقتضى مذاهب الإنب الفقهاء والأصوليّين

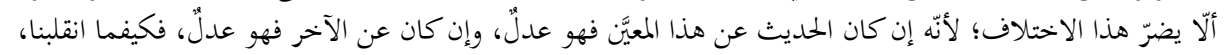

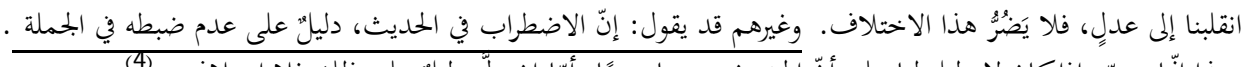

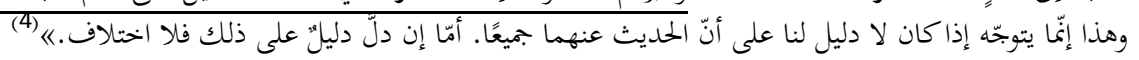

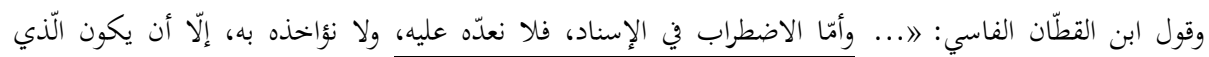

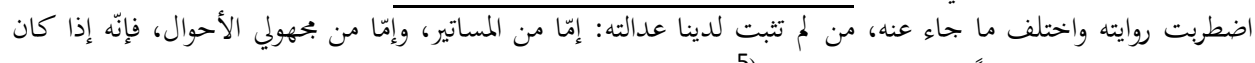

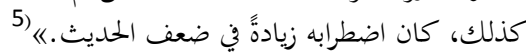

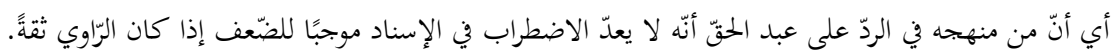

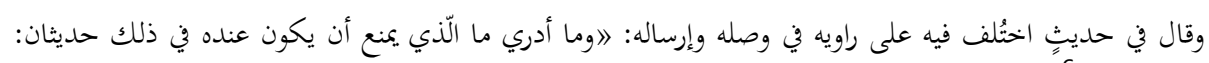

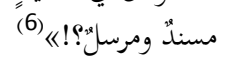

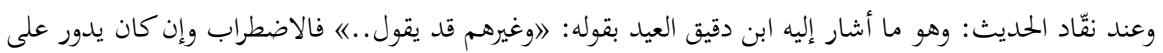

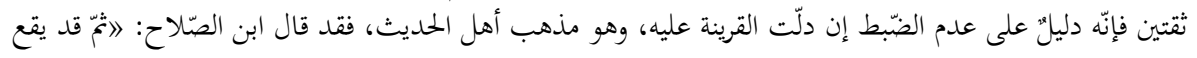

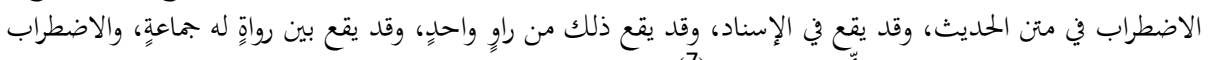

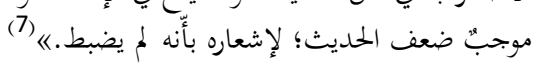

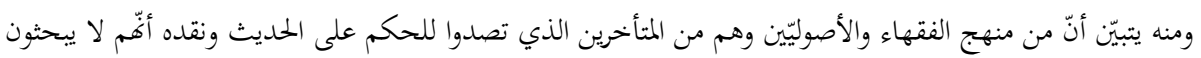

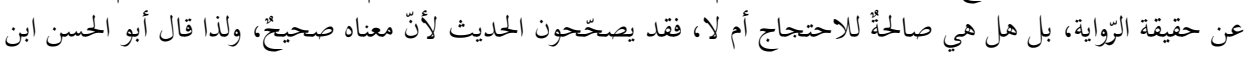

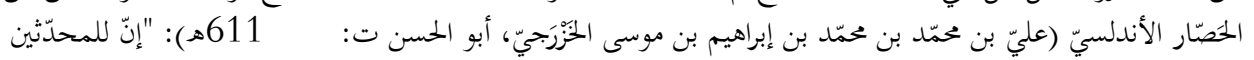

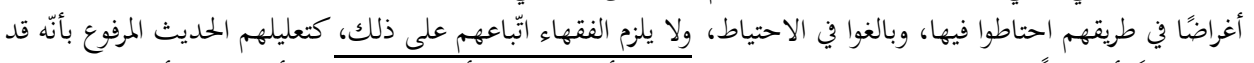

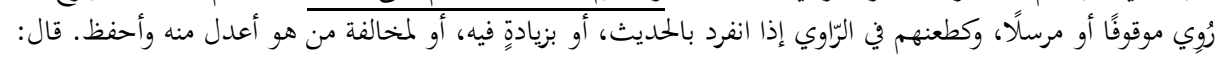

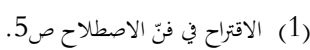

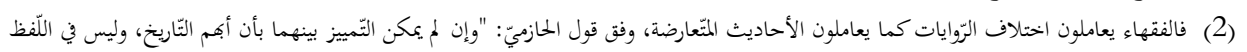

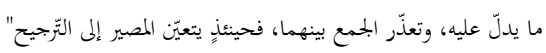

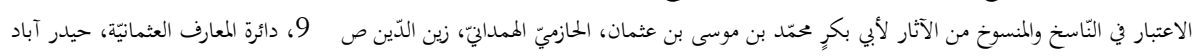

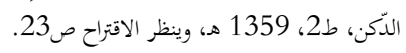

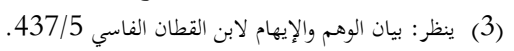

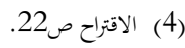

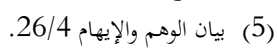

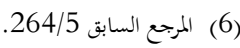
(7) علوم الحديث لابن الصَّلاح ص94. 


\section{6 | Abdel Gani ADA}

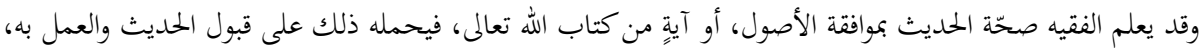

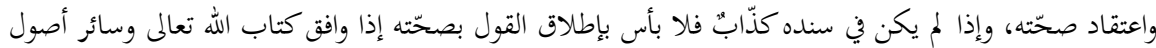

(1)" الشّريعة.

أمّا النّقّاد من المحدّثنين فيجمعون الطّرق ويمحّصوها، ويعلّلون الحديث من طريقِ وإن كان من طريقِ أخرى صحيحًا.

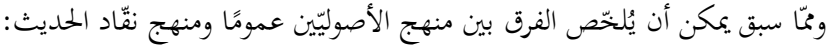

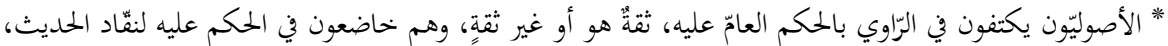

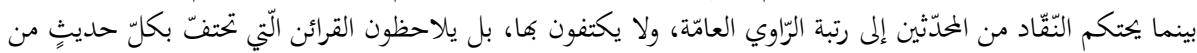
أحاديثه، والّتي تدلّ على صوابه أو وهمه.

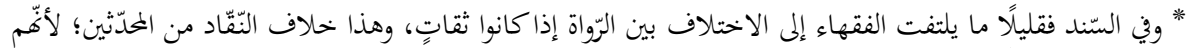

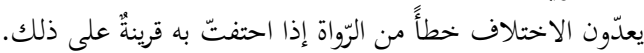

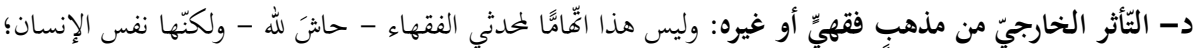

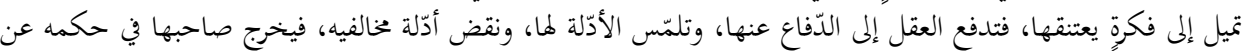

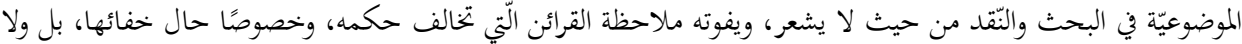

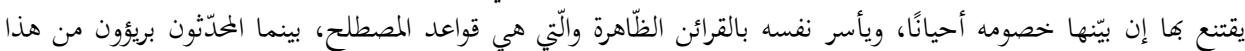

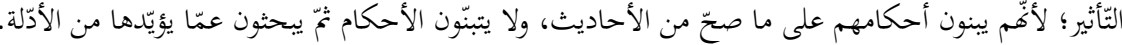

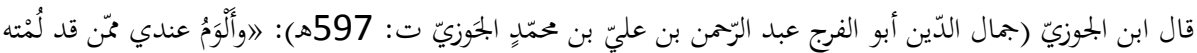

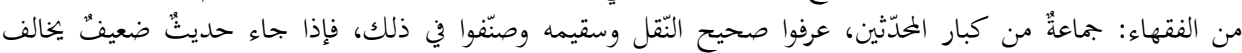

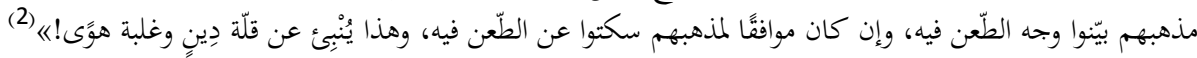

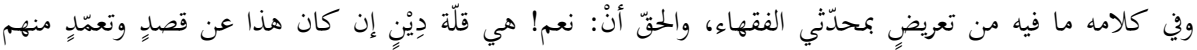

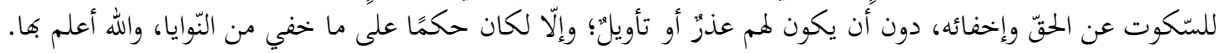

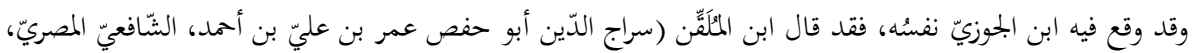

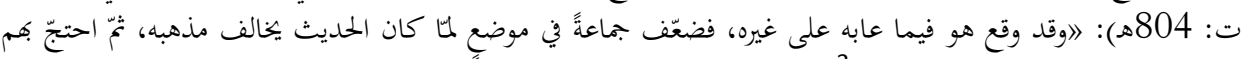

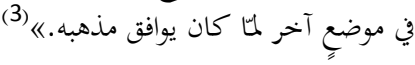

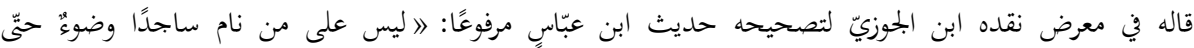
(4) يضطجع.. (4)

(1) نقله الزركشي عنه من تقريب المدارك على موطأ مالك. ينظر: النكت على مقدمة ابن الصلاح للززركي 106/1.

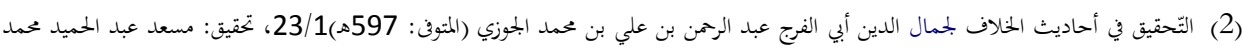

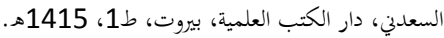

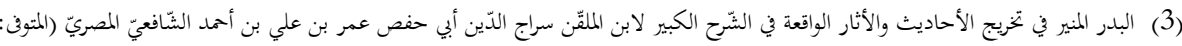

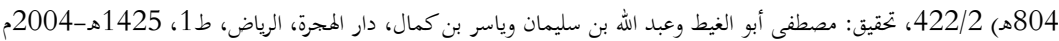

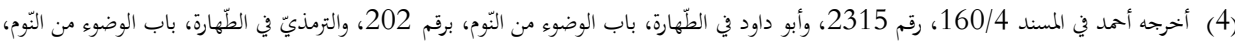

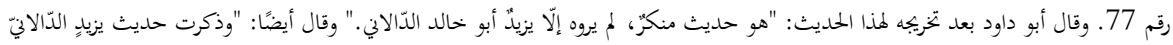

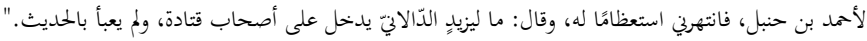

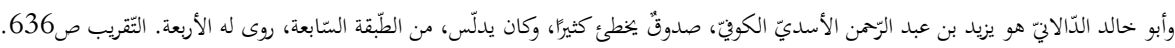


217 | أهلية المتأخرين في الحكم على الحديث بين النظرية والتطبيق

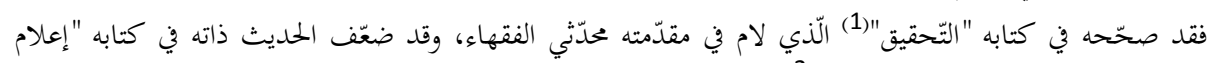

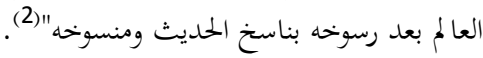

بل هي إذاً _كما أسلفت أولًاً__النّس البشريّة تتأثّر بما تميل إليه، وتوقع صاحبها في الزّلّل.

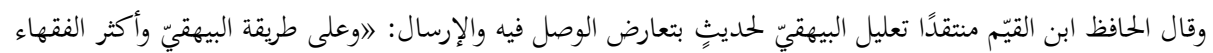

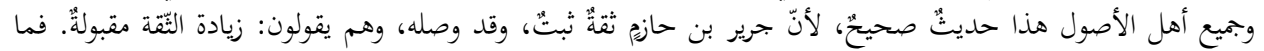

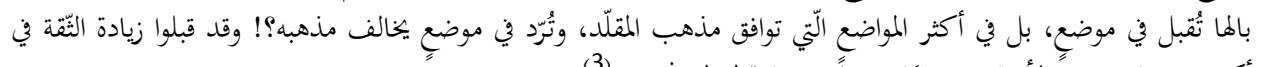

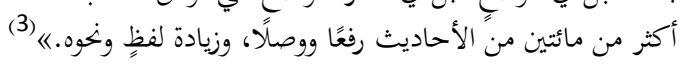

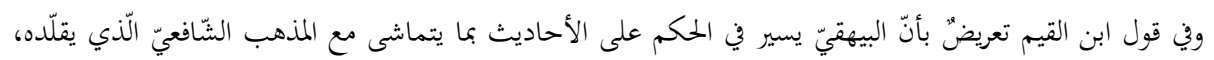

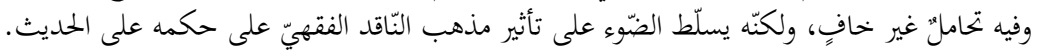

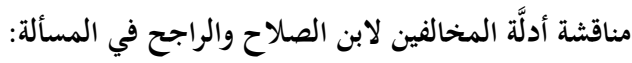

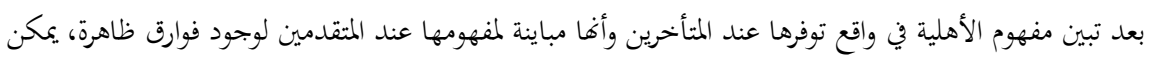
مناقشة أدلة المخالفين لابن الصلاح في مسألة تصحيح المتأخرين:

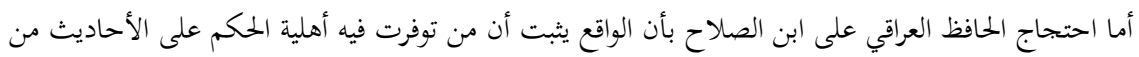

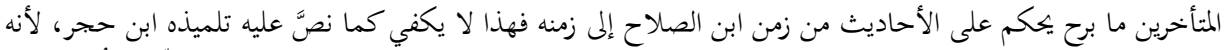

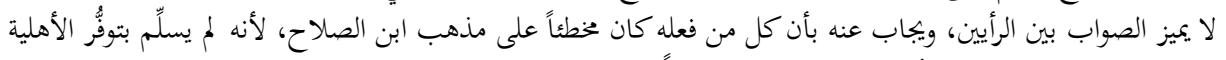

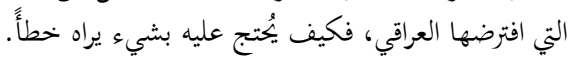

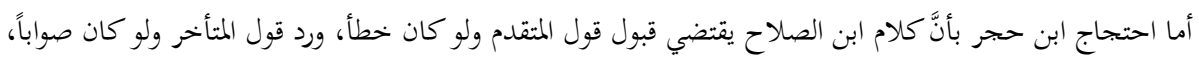
فليس بلازم على ابن الصلاح من وجهين:

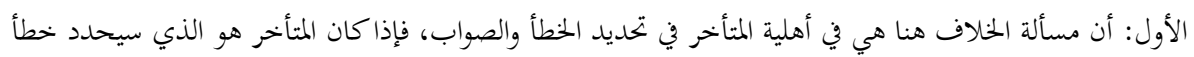

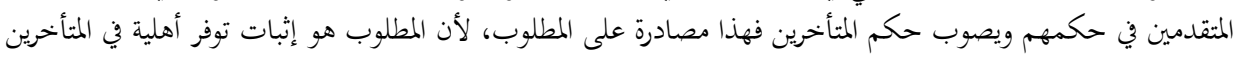
تساوي أهلية المتقدمين، فإذا توفرت ويصوب حان الحكم منهم مقبولاً.

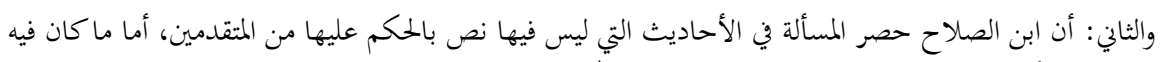

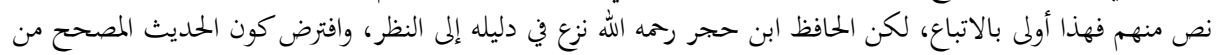

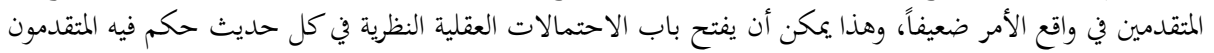

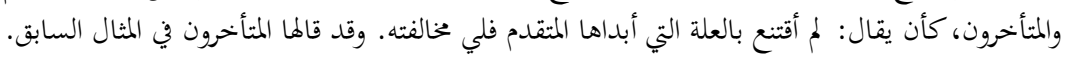

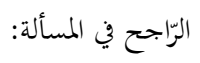

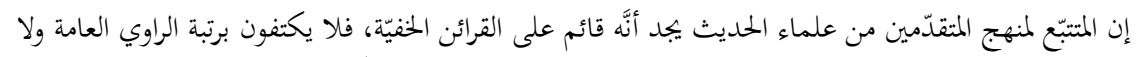

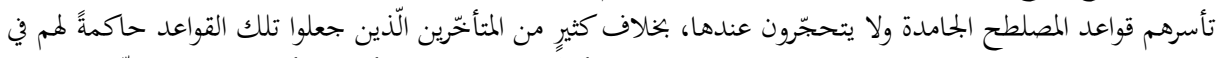

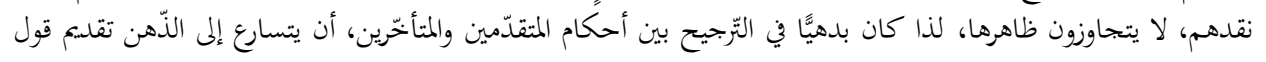

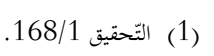

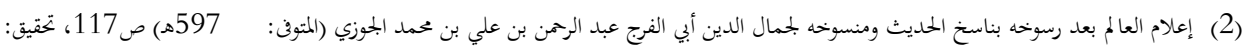

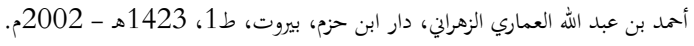

(3) ماشية ابن القيّم على سن أبي داود 85/6. 


\section{8 | Abdel Gani ADA}

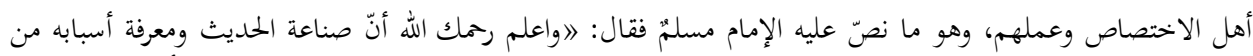

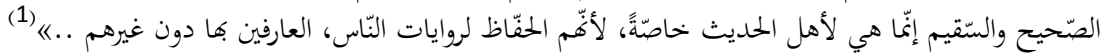

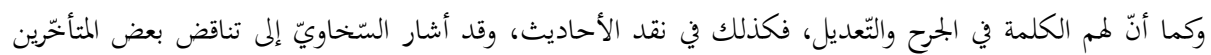

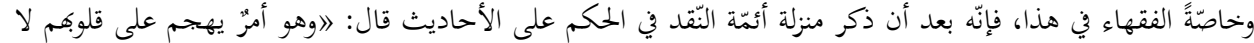

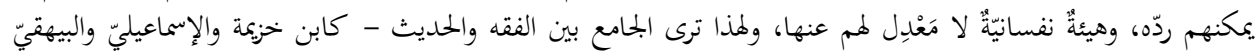

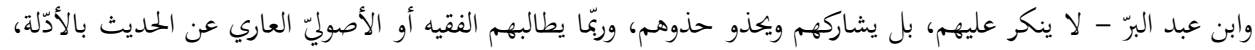

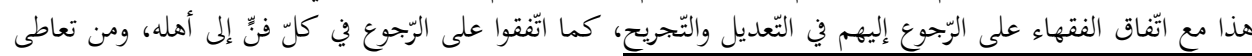

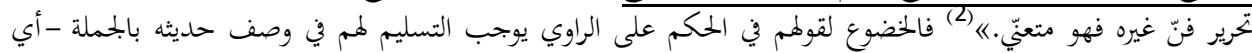

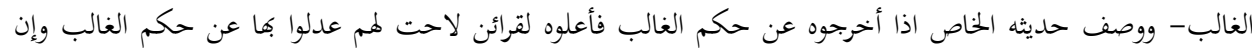
كان ظاهر ذلك الحديث الصحة.

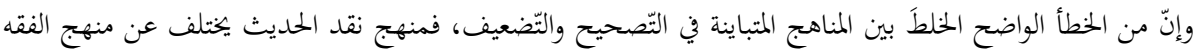

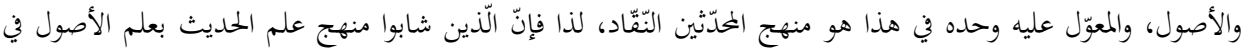

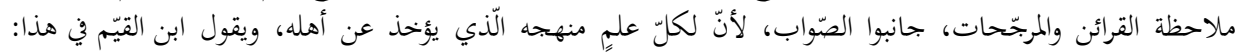

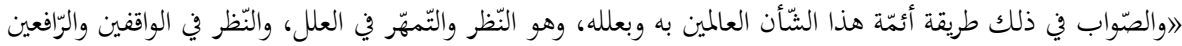

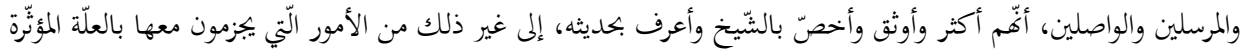

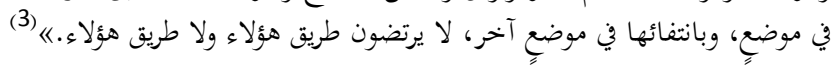

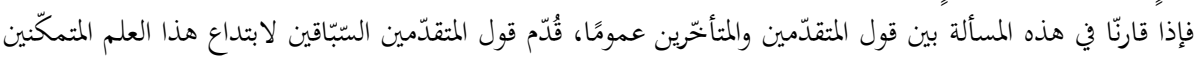

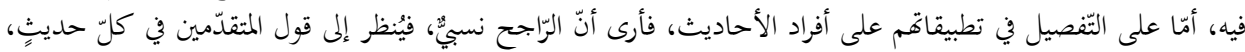

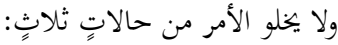

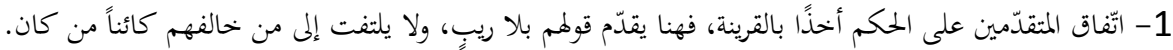

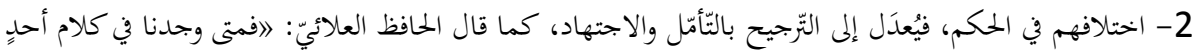

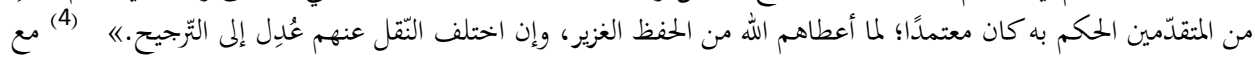
ملاحظة تفاضلهم في المكانة العلمية والملكة الفكرية.

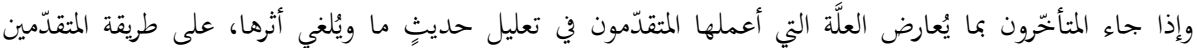

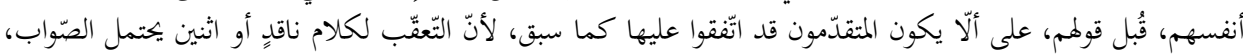

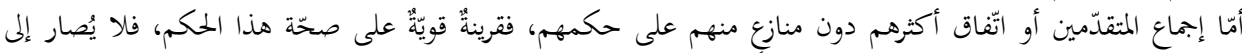

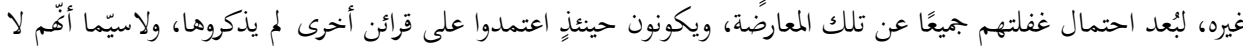

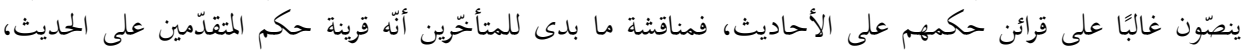

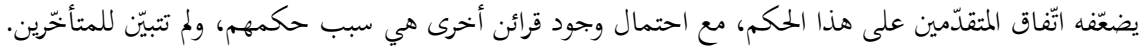

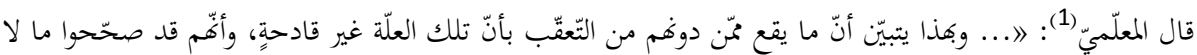

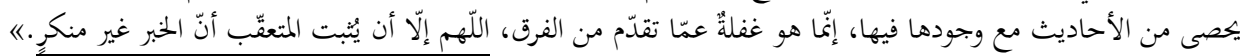

(1) كتاب التّمييز لمسلم بن الحجاج أبي الحسن القشيري النّيسابوريّ ص 218، تحقيق: د. عممد مصطفى الأعظمي، مكتبة الكوثر، المربع، السعودية، ط3، 
219 | أهلية المتأخرين في الحكم على الحديث بين النظرية والتطبيق

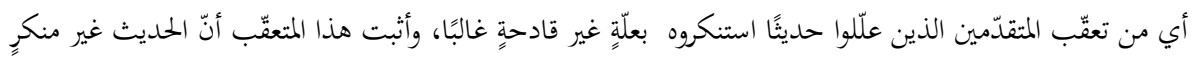

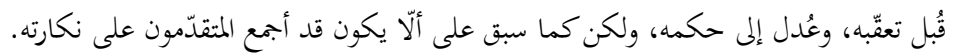

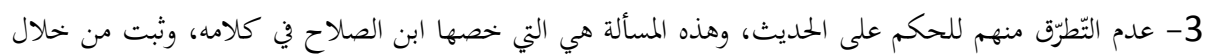

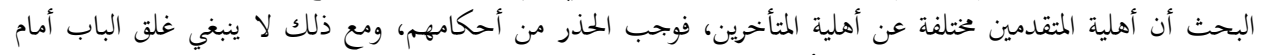

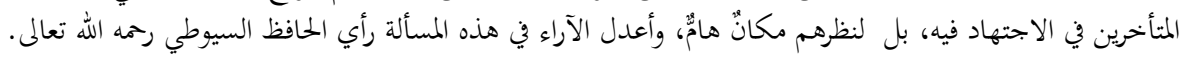

\section{رأي الحافظ السيوطي في مسألة تصحيح المتأخرين:}

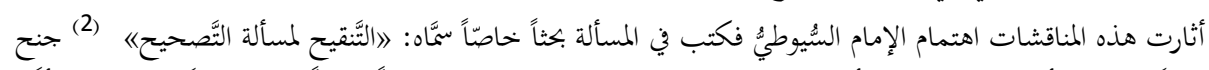

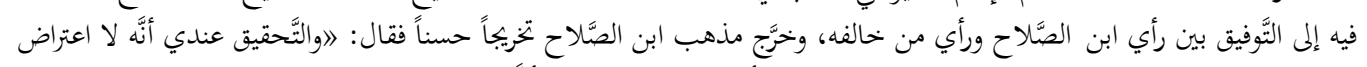

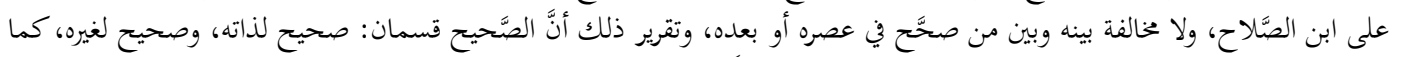

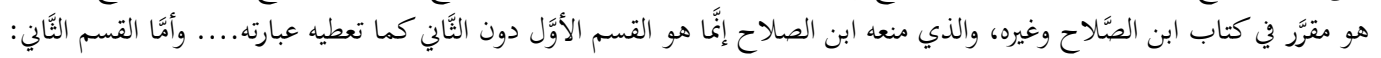

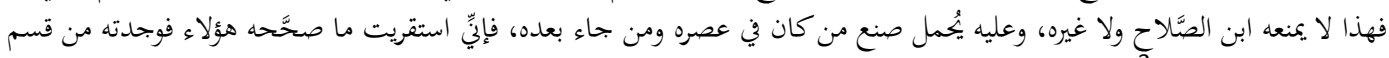

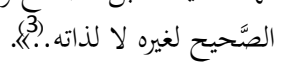

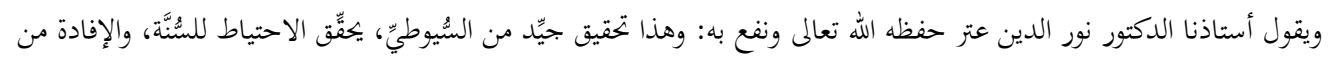

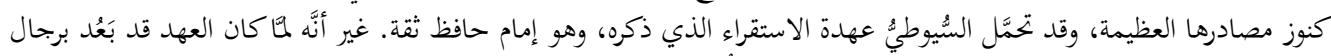

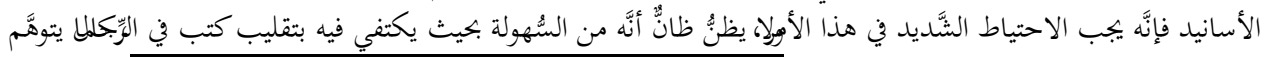

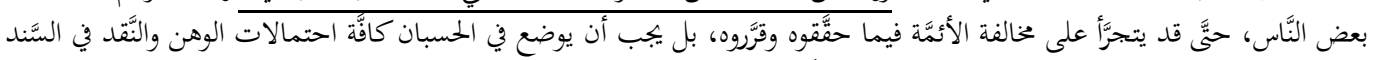

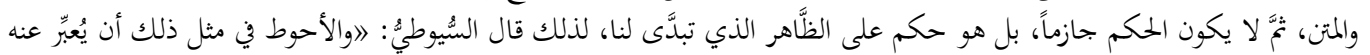

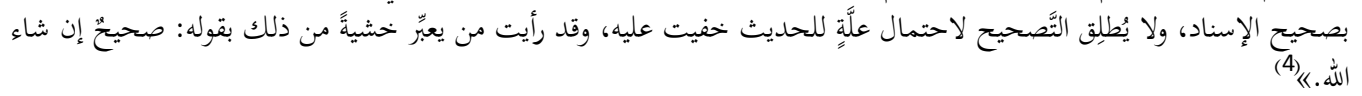

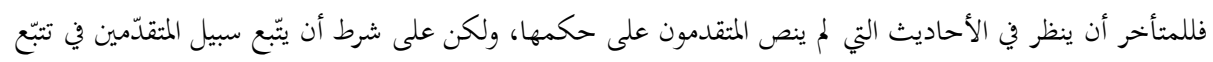

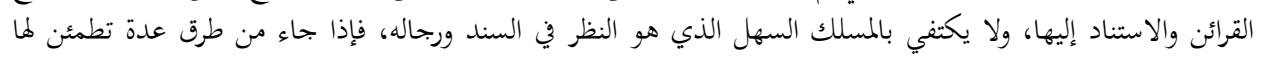

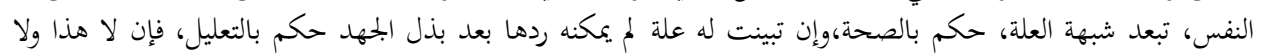

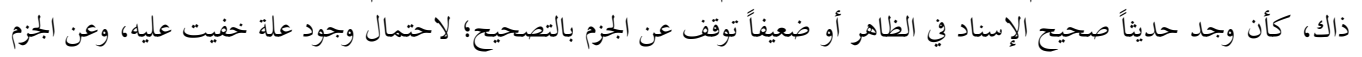

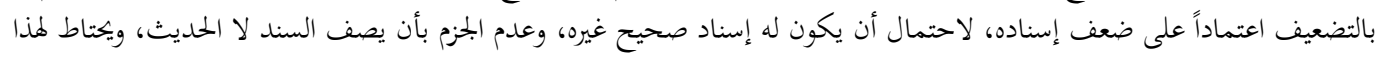
بأن يتبع حكمه بقوله: إن شاء الله.

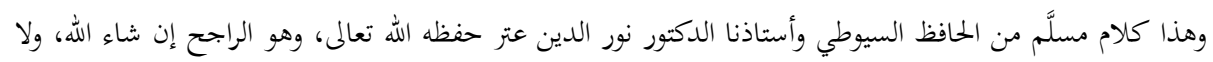

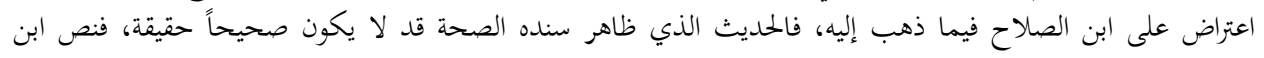

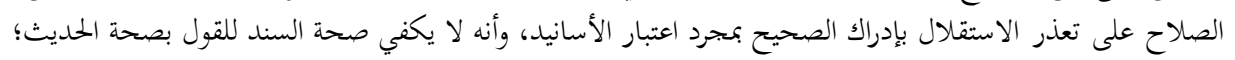

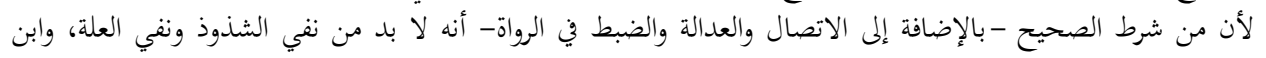

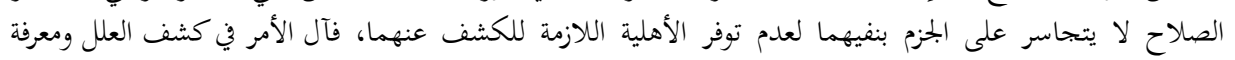

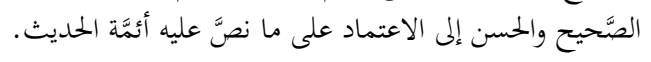

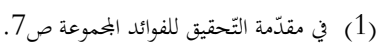

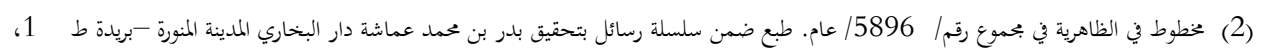
1995

$$
\begin{aligned}
& \text { (3) (3) التنقيح لمسألة الصحيح ص21. } \\
& \text { (4) تدريب الراوي للسيوطي 148/1. وينظر: منهج النقد في علوم الحديث ص282. }
\end{aligned}
$$


وحَسُن في الختنام أن أسجّل أهمّ النّائج الّتي توصّلت إليها في هذا البحث، ثمّ أسجّل أهمّ التّوصيات الّتّي رأيتها من

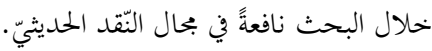

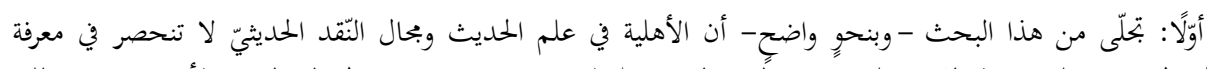

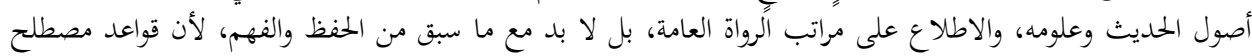

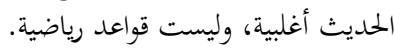

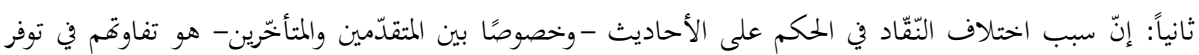
الأهلية فيهم.

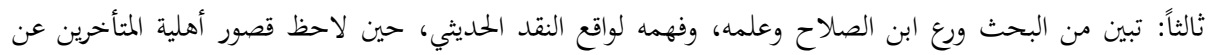

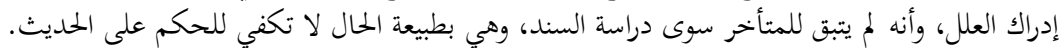

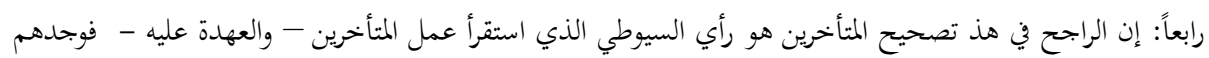

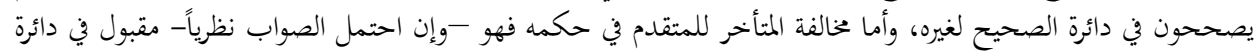

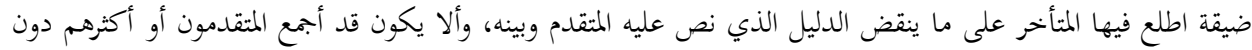

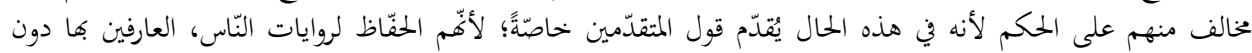

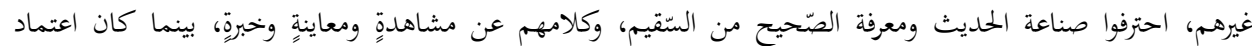

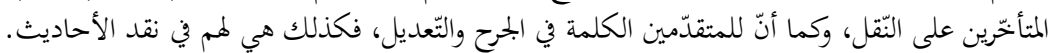

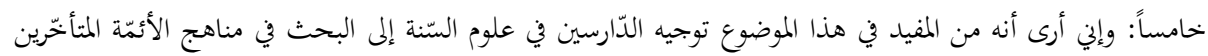

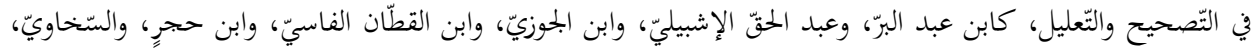

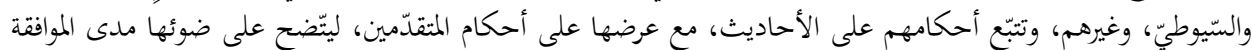

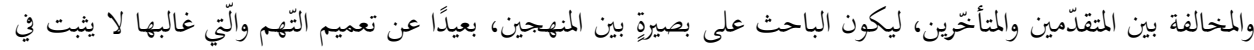
حقّ كثيرٍ من المتأخّرين بمخالفتهم للمتقدّمين.

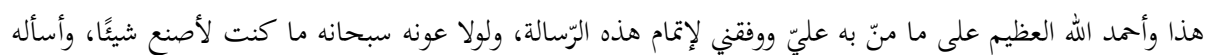

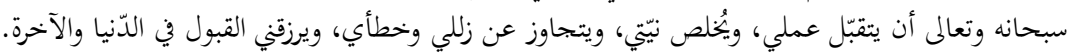




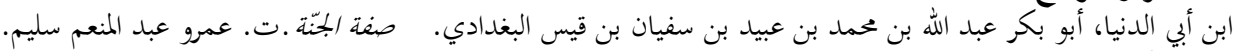
1 أبحلد. القاهرة: مكتبة ابن تيمية.

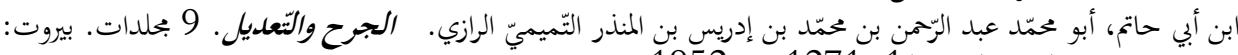

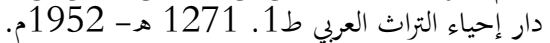

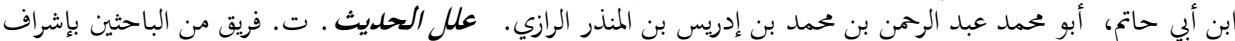

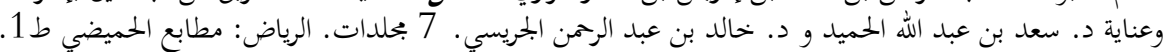

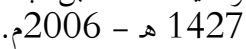

ابن التركماني، علاء الدّين عليّ بن عثمان بن إبراهيم بن مصطفى الماردينيّ. الجوهر التّقيّ على سنن البيهتيّ. 10

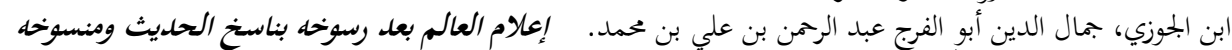

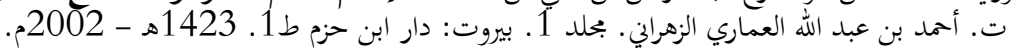

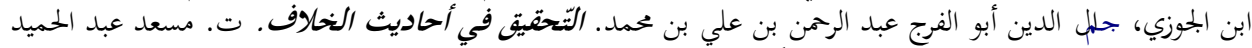

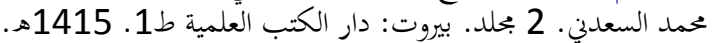

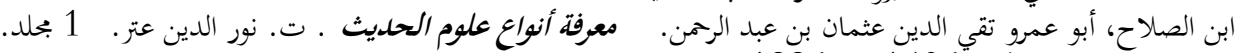

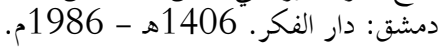

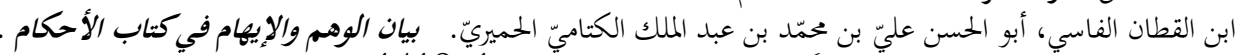

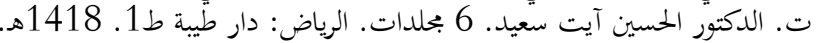

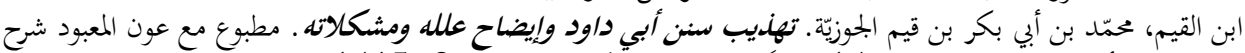

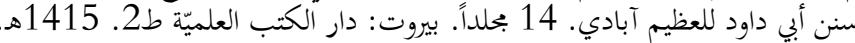

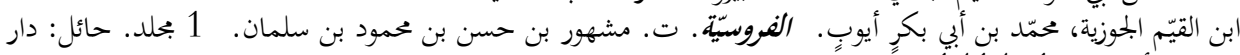

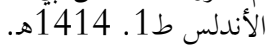

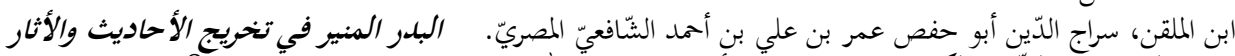

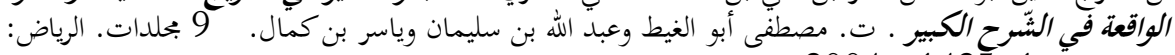

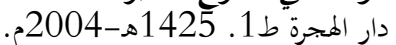

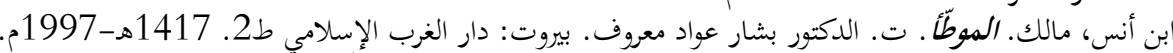

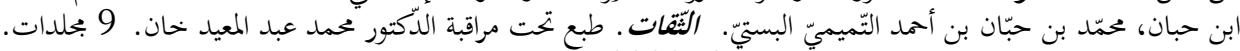

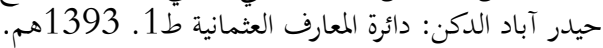

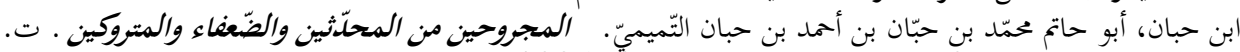

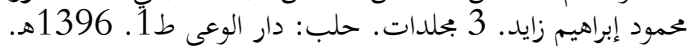

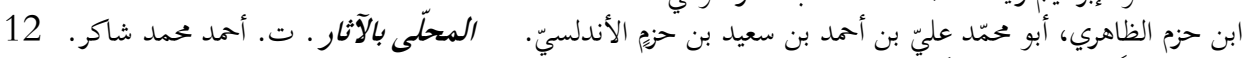

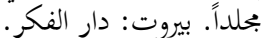

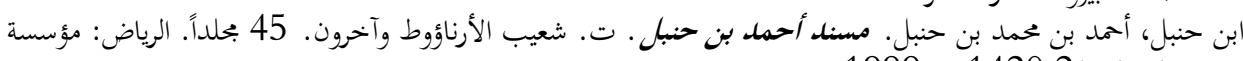

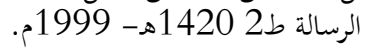
ابن دقيق العيد، أبو الفتح محمد بن علي بن وهب بن مطيع القشيري. الاقتراح في بيان الاصطلاح. 1 بمحلد. بيروت: دار

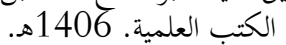
ابن كثير، أبو الفداء إسماعيل بن عمر بن بن كثيرِ الدّمشقيّ. الباعث الحثيث إلى انتصار علوم. ت. أحمد محمّد شاكر. بمحلد

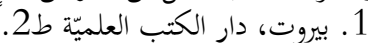

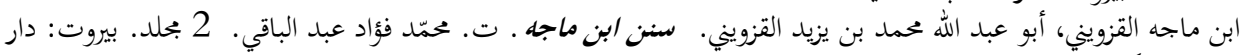

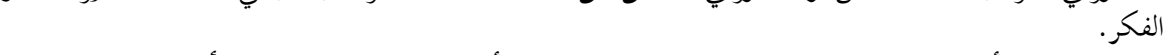

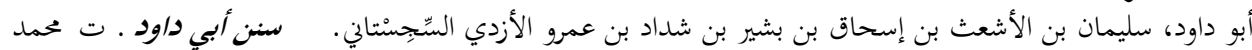

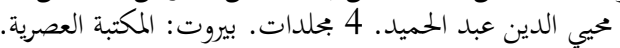

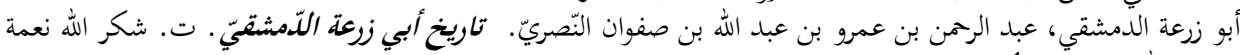
الله القوجأيّي. 1 بحلد. دمشق الدمن بحمع اللغة العربيّة. 
222 | Abdel Gani ADA

البخاريّ، أبو عبد الله محمّد بن إسماعيل الجعفيّ. صحيح البخاريّ. ت. محمّد زهير بن ناصر النّاصر. 9 بحلدات. بيروت:

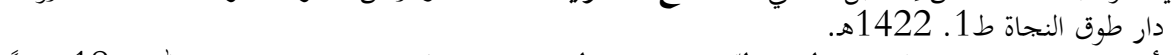

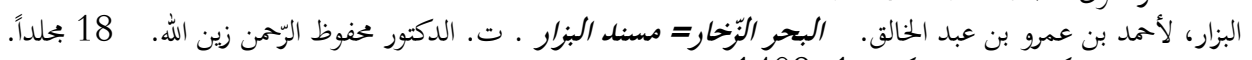

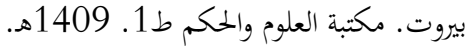

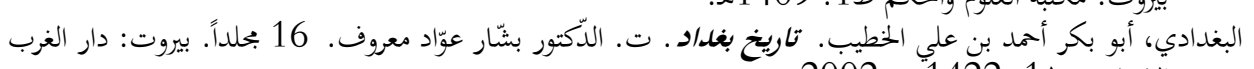

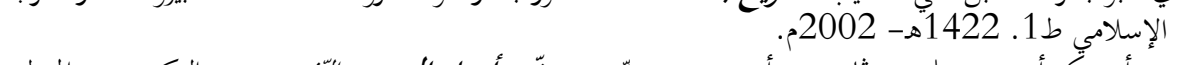

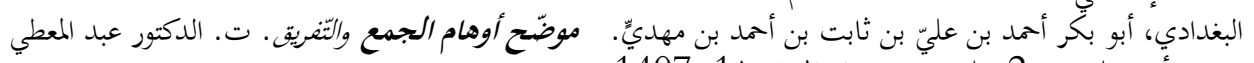

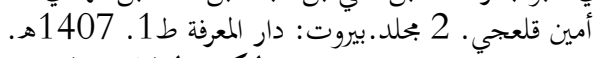

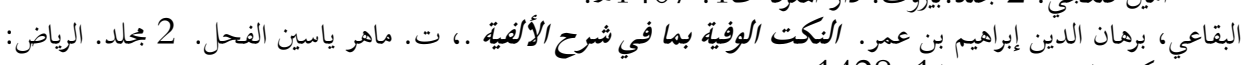

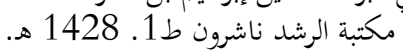

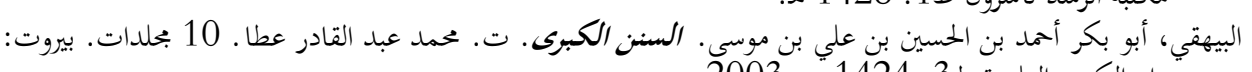

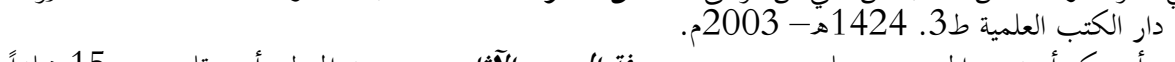

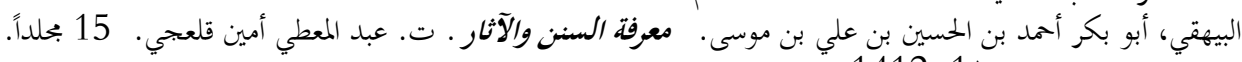

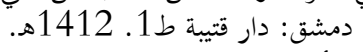

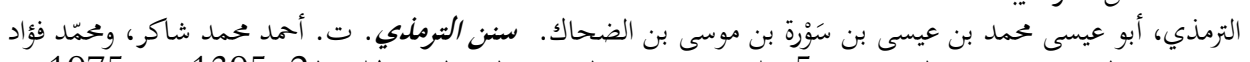

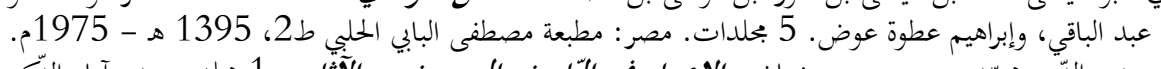

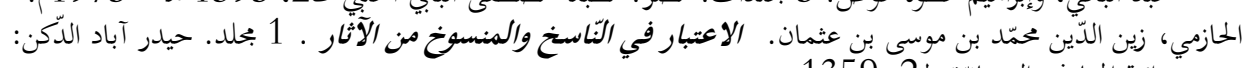

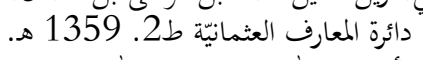

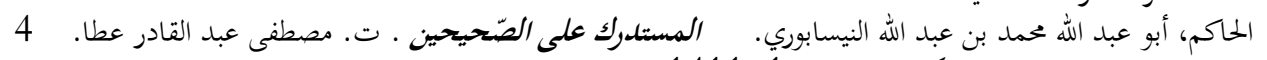

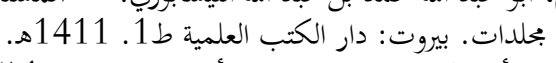

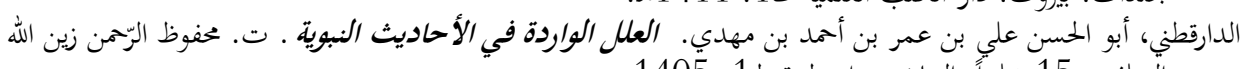

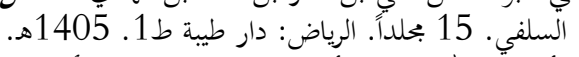

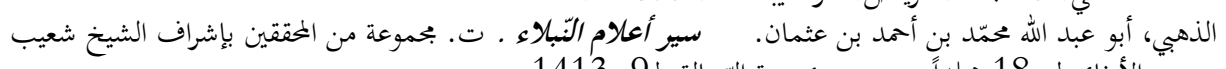

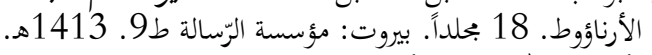

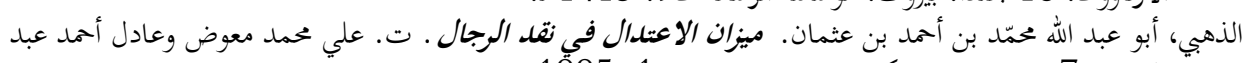

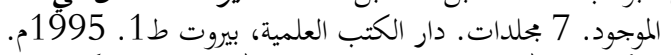

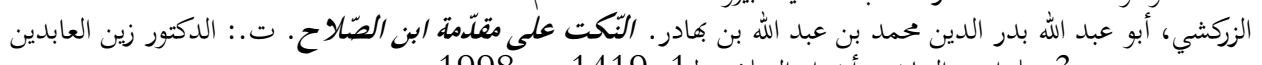

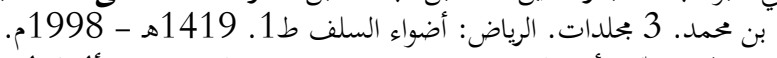

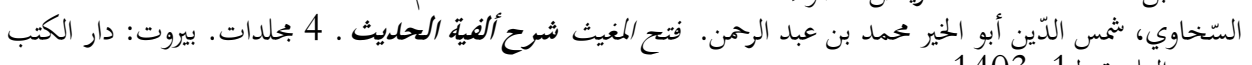

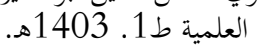

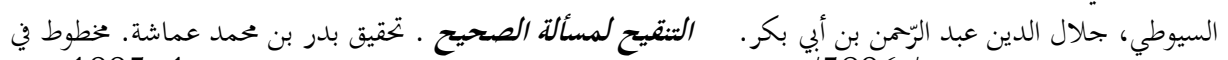

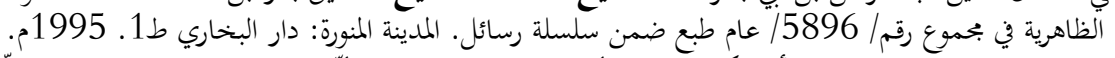

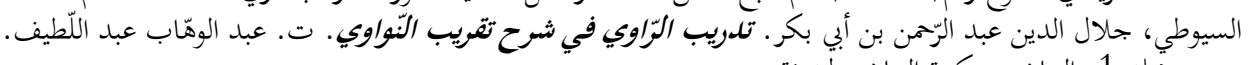
الشوكاني، محمد 1. الرياض: ملي بن محتبة الرياض الفوائلد المجيثة.

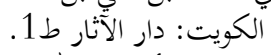

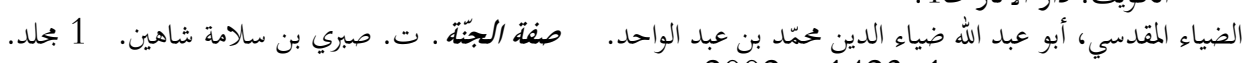

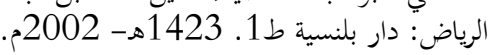

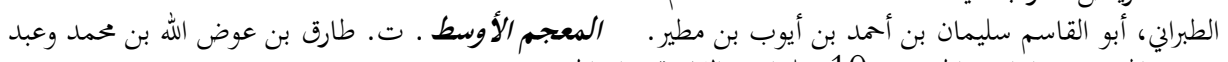

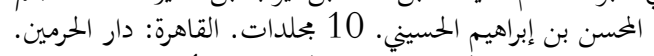

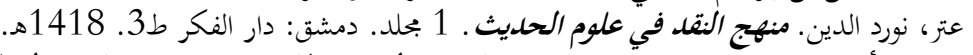

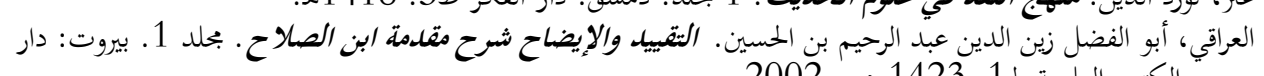

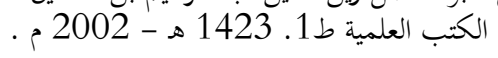


223 | أهلية المتأخرين في الحكم على الحديث بين النظرية والتطبيق

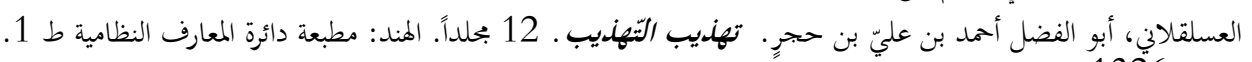
1326هـ ألئ.

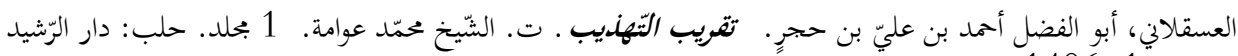

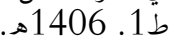
العسلقلاني، أبو الفضل أحمد بن عليّ بن حجرٍ. التّلخيص الحبير في تخريج أحاديث الرافعي الكبير بيروت: دار

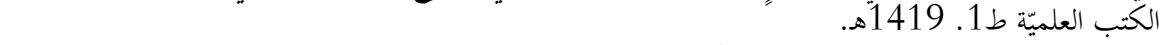

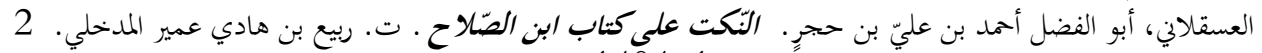

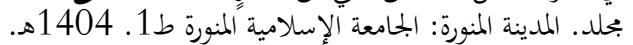

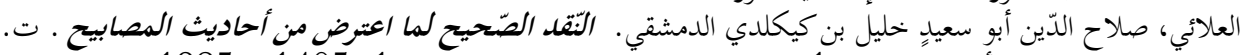

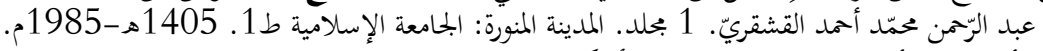

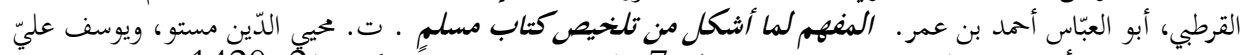

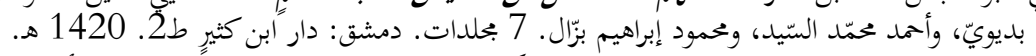

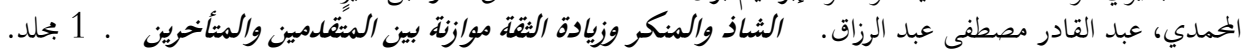

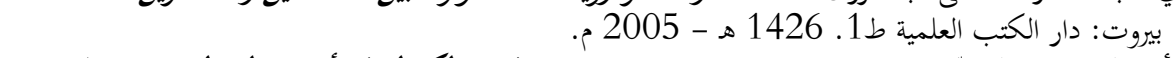
المزي، أبو الحجاج، جمال الدّين يوسف العلفية بن عبد الرحمن بن يوسف.

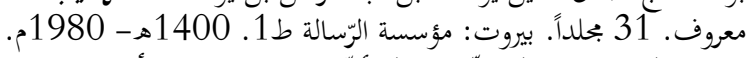

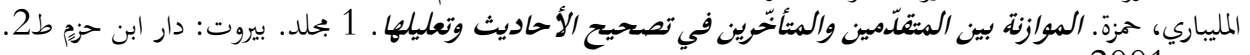

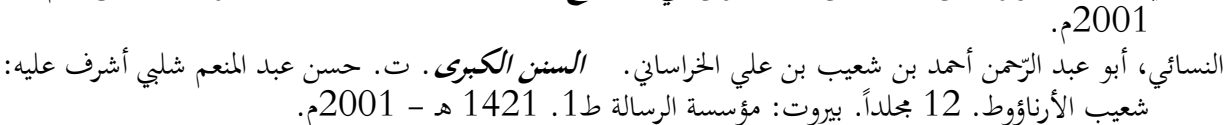

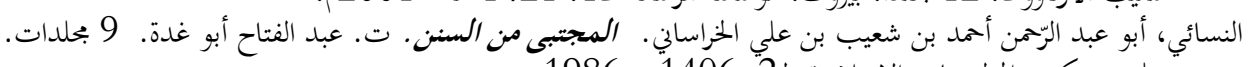

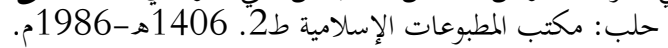

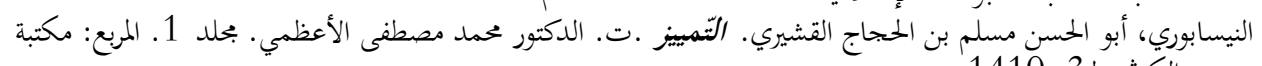

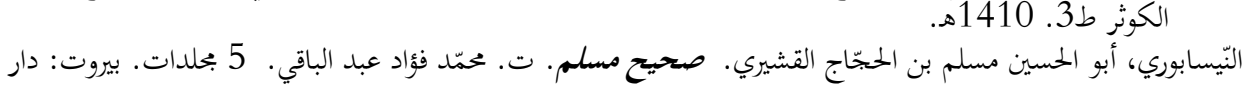
إحياء التراث العربي.

Akgün, Hüseyin. Mă̆ribli Muhaddis İbnü'l-Kattân'ın Hadis Anlayışı. Ankara: Gece Kitaplığı Yayınları, 2014. 